Discussion Paper No. 06-019

\title{
Rising Wage Inequality in Germany
}

Johannes Gernandt and Friedhelm Pfeiffer

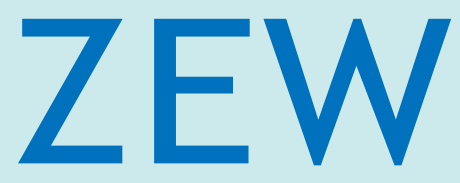

Zentrum für Europäische Wirtschaftsforschung $\mathrm{GmbH}$

Centre for European

Economic Research 
Discussion Paper No. 06-019

\title{
Rising Wage Inequality in Germany
}

\author{
Johannes Gernandt and Friedhelm Pfeiffer
}

Download this ZEW Discussion Paper from our ftp server:

ftp://ftp.zew.de/pub/zew-docs/dp/dp06019.pdf

Die Discussion Papers dienen einer möglichst schnellen Verbreitung von neueren Forschungsarbeiten des ZEW. Die Beiträge liegen in alleiniger Verantwortung der Autoren und stellen nicht notwendigerweise die Meinung des ZEW dar.

Discussion Papers are intended to make results of ZEW research promptly available to other economists in order to encourage discussion and suggestions for revisions. The authors are solely responsible for the contents which do not necessarily represent the opinion of the ZEW. 


\section{Non technical summary}

This paper contributes to the ongoing debate on rising wage inequality. Based on the GSOEP 1984 to 2004 the evolution of wage inequality is investigated separately for West Germany between 1984 and 2004, and compared to the evolution of inequality in East Germany between 1994 and 2004. Our central measure of wage inequality is the $90^{\text {th }}$ to $10^{\text {th }}$ percentiles of real gross hourly wages, as well as its two sub-groups, $90^{\text {th }}$ to $50^{\text {th }}, 50^{\text {th }}$ to $10^{\text {th }}$. Two samples of workers, one for all workers including the self-employed and one for the group of prime age dependent male workers, have been drawn from the GSOEP. The increase in wage inequality is decomposed econometrically into a composition, a price and a residual effect. Not surprisingly, the paper confirms the well known stability of the West German wage distribution for the period 1984 to 1994. Wage inequality started to rise around 1994 in the sample for prime age dependent male workers in both parts of Germany. In the sample for all workers, including the self-employed, the trend towards rising wage inequality started around 1996. The main reason for this lag is that there is no rising inequality for the group of self-employed worker, although the level of inequality is higher compared to wage worker.

The evolution of wage inequality differs in East compared to West Germany. Rising wage inequality in West Germany primarily occurred in the lower part of the wage distribution, and wage inequality in East Germany primarily occurred in the upper part of the wage distribution. These differences presumably are due to the adjustment processes of the two parts of Germany and the induced competition for high wage workers. Surprisingly, the evolution of wage inequality in East Germany seems to have some similarities to the evolution of wage inequality in the United States in the 80s.

There are some more interesting and economically meaningful results from the econometric decomposition analysis. For West German workers residual wage inequality "explains" roughly two thirds of rising inequality, with composition and price effects accounting for one third of the rising inequality. For East German workers residual wage inequality "explains" roughly 40 percent, whereas price effects account for roughly 50 percent of the rising inequality.

Rising wage inequality seems to be a general trend in the sense that it is not restricted to wage workers with specific characteristics, although it is quantitatively more pronounced among low skilled workers and workers with low tenure in West Germany. High rates of unemployment, presumably reinforced by non-neutral technical change, led to wage adjustment primarily through wage decreases for the low skilled and for entrants. Wages for workers with longer years of tenure are more rigid and firm's adjustment for this group of employees takes place primarily through reduction in employment and hours of work. 


\title{
Rising Wage Inequality in Germany
}

\author{
Johannes Gernandt* and Friedhelm Pfeiffer** \\ *ZEW Mannheim \\ ** ZEW Mannheim, University of Mannheim
}

\begin{abstract}
:
This paper investigates the evolution of wages and the recent tendency to rising wage inequality in Germany, based on the German Socio-Economic Panel (GSOEP) for 1984 to 2004. Between 1984 and 1994 the wage distribution was fairly stable. Wage inequality started to increase around 1994 in Germany for all workers and for prime age dependent male workers as well. Rising inequality is not the result of the recent rise in self-employment. In West Germany rising inequality occurred in the lower part of the wage distribution, in East Germany in the upper part of the wage distribution. While residual wage inequality accounted for two-thirds of rising wage inequality in West Germany, in East Germany price effects dominated. In West Germany the group of workers with low tenure experienced higher inequality.
\end{abstract}

\section{Keywords:}

Education, tenure, skill composition, wage inequality, wage rigidity.

\section{JEL-classification:}

J21, J24, J31

\section{Acknowledgements:}

Friedhelm Pfeiffer acknowledges financial support form the Germany Science Foundation under grants PF 331/2 ("Microeconometric Methods to Assess Heterogeneous Returns to Education") and PF 331/3 ("Wages, Rent-Sharing and Collective Wage Bargaining”). For very helpful comments for an earlier version of this paper we would like to thank Bernhard Boockmann, Alfred Garloff, Blaise Melly and Reinhold Schnabel as well the participants at the Friday workshop, ZEW. For competent research assistance we thank Tim Landvoigt, Volker Ludwig and Julie RatWirtzler. The usual disclaimer applies. 


\section{Introduction}

The evolution of wages and wage inequality are of central importance for the functioning of the labour market, for individual wellbeing and the development of the economy. Economics has a long tradition in studying among others the role of education and tenure as well as institutions or the computer revolution for wages and wage inequality. Rising wage inequality in the United States and the United Kingdom in the 1980s has attracted a considerable amount of research and intensive debates among empirical economists. ${ }^{1}$ A long time this has been contrasted with a rather stable wage distribution in Germany. The German wage structure was compressed from below and for the low skilled, a result attributed to union power in the German system of central wage bargaining and employment protection laws. ${ }^{2}$

Some degrees of wage flexibility, at least in parts of the German wage distribution, has been reported by Bellmann and Gartner (2003) for high educated workers, by Fitzenberger et al. (2001) for young workers with intermediate education levels, by Riphahn (2003) for foreigners, by Möller (2005) for wages in the lower part of the wage distribution and in East Germany after unification by Steiner and Hölzle (2000). Microeconometric studies on wage rigidity and the wage sweep-up for West Germany indicate that wage rigidity is highest in the middle part of the wage distribution and for workers with more than five years of tenure (Pfeiffer, 2003), whereas wages are more flexible for entrants and outside central wage bargaining. Table A1 in the appendix provides a summary of previous microeconometric studies on the evolution of wage inequality in Germany.

This paper contributes to the ongoing debate by empirically investigating the evolution of the wage distribution in Germany based on the GSOEP over the period 19842004. Our contribution is fourfold: First, the paper provides evidence for the most recent relatively strong rise in wage inequality. Second, the role of educational qualification and other factors, especially tenure, occupational status and gender is analysed relative to the role of unobserved factors that determine wages and its distribution over time, based on the Juhn et al. (1993) decomposition method. One focus is on the role of educational qualification since the demand for cognitive skills has increased in the course of the computer revolution (Spitz-Oener, 2006) and the German system of early ability tracking seems to raise inequality in student achievement scores (Schuetz et al., 2005).

\footnotetext{
${ }^{1}$ See Acemoglu (2002), Autor et al. (2005a, b), Blau and Kahn (1996), Budria and Pereira (2005), DiNardo et al. (1996), Gottschalk and Smeeding (1997), Juhn et al. (1993), Katz and Autor (1999), Meghir and Whitehouse (1996), among others.

${ }^{2}$ See the discussions in Bellmann and Gartner (2003), Fitzenberger and Franz (2001), Fitzenberger and Kohn (2005), Kahn (2000), Prasad (2004) and Steiner and Hölzle (2000) among others. The issue has been highlighted by Krugman (1994) who argued that rising inequality in the United States and rising unemployment in Europe are just the two sides of one coin.
} 
Another focus is on assessing the role of tenure and experience for the evolution of wage inequality, since entrants into the labour market face strong competition due to high unemployment rates in Germany (see Gernandt and Pfeiffer, 2006). Third, the contribution of self-employed workers for rising inequality is investigated. In Germany the number of self-employed workers has been growing steadily in the observation period (see Pfeiffer, 2005) and we would like to study its impact on some aspects of wage inequality in Germany. Fourth, the paper compares the evolution of wage inequality in East and West Germany.

The work on the evolution of wages as reported in this paper was motivated by some descriptive evidence, which is covered briefly as an introduction to the issue of rising wage inequality in Germany. Our central measure of wage inequality is the $90^{\text {th }}$ to $10^{\text {th }}$ percentiles of real ${ }^{3}$ gross hourly wages, as well as its two sub-groups, $90^{\text {th }}$ to $50^{\text {th }}, 50^{\text {th }}$ to $10^{\text {th }}$. Two samples of workers, one for all workers including the selfemployed and one for the group of prime age dependent male workers, have been drawn from the GSOEP (see section 3). For the sample of prime age dependent male workers, Figure 1 indicates rising wage inequality measured by the 90 to 10 percentiles distance (the wages at the percentiles are indexed to 1 in 1984) starting somewhere between 1992 and 1994 in West Germany. The wage distribution was fairly stable before (a result that has been reported in the literature, see the discussion above).

For the GSOEP sample of all workers Figure 1 indicates rising wage inequality measured by the 90 to 10 percentiles distance starting in the late 1990s in West Germany, while the 90 to 50 percentiles remain roughly constant over time. Not surprisingly, however, in the early 1990s wages were more compressed, according to the 90 to 10 percentiles measure. Over the observation period, wages at the $90^{\text {th }}$ and $50^{\text {th }}$ percentiles increased by roughly $35 \%$, while the wages at the $10^{\text {th }}$ percentile only increased by $25 \%$. There was even a fall in wages up to the $25^{\text {th }}$ percentile since 1996.

The evolution of wages and wage inequality in East Germany differs considerably from that in West Germany, Figure 2. In the adjustment process to the market economy wage inequality rose even faster than in West Germany. Surprisingly, the development in East Germany between 1994 and 2004 seems to be more similar to the evolution of wage inequality in the US between 1979 and 1988, as reported in Juhn et al. (1993), compared to the evolution of wages in West Germany. A further difference from West Germany is that the larger part of wage inequality occurred in the part of the wage distribution that is above the median.

\footnotetext{
${ }^{3}$ All wages are deflated with the Consumer Price Index for Germany, base year 2000, taken from Statistisches Bundesamt (2005).
} 
Figure 1: The Evolution of Wages, West German Workers 1984-2004
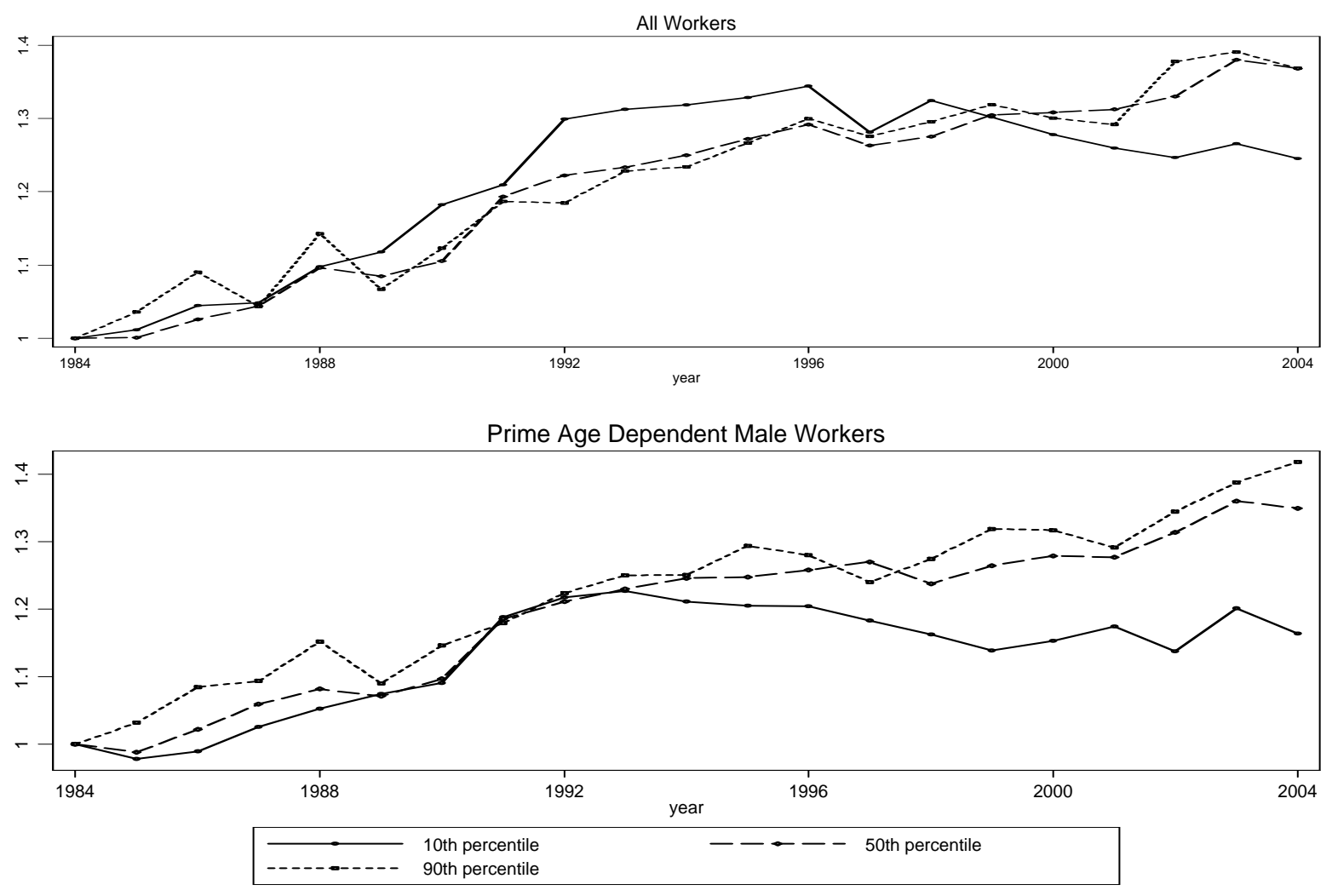

Source: GSOEP 1984-2004, own calculations based on cross-section weights; all wages for the three percentiles are normalized to 1 in 1984.

Figure 2: The Evolution of Wages, East German Workers 1994-2004
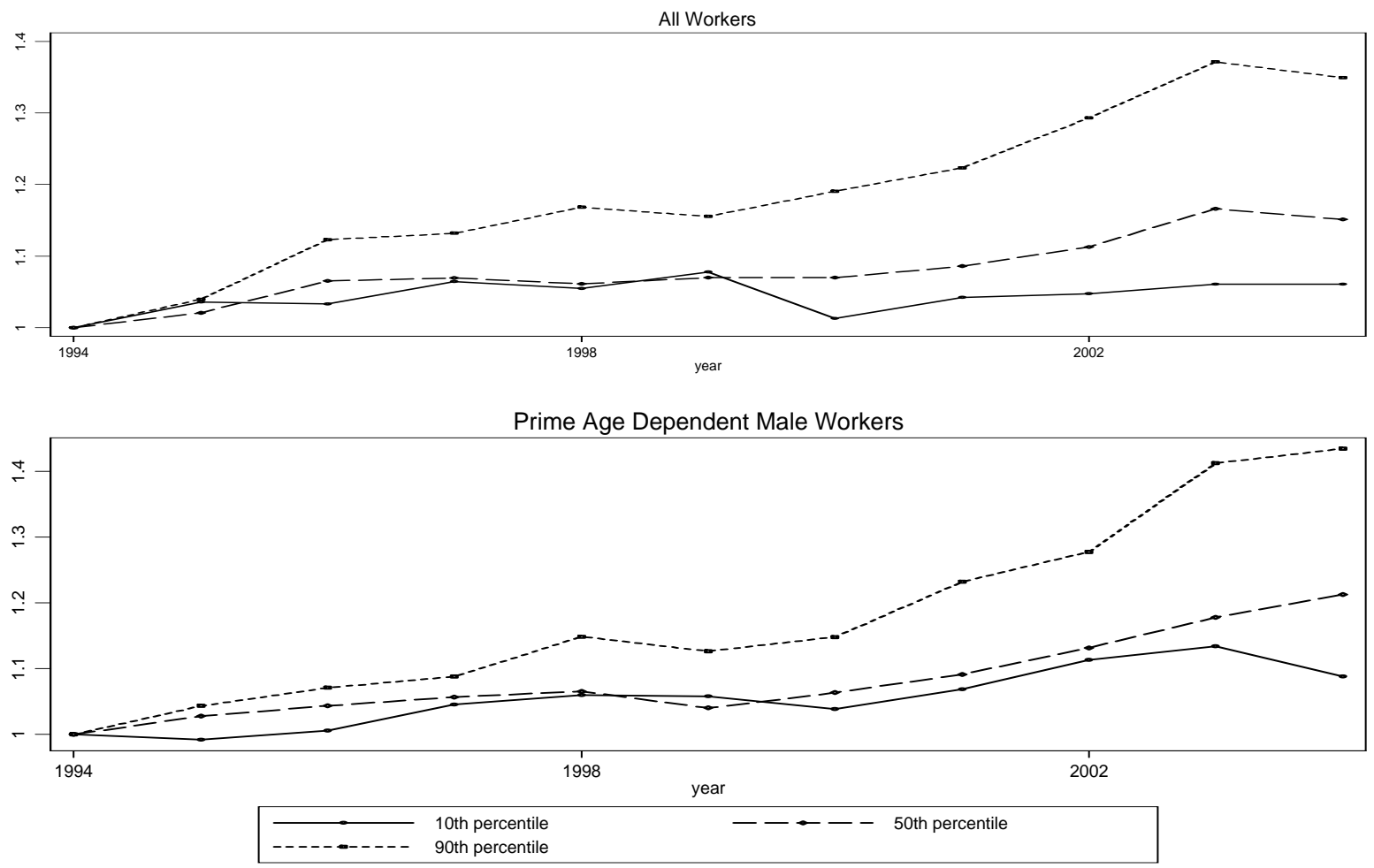

Source: GSOEP 1994-2004, own calculations based on cross-section weights; all wages for the three percentiles are normalized to 1 in 1994. 
The evidence from earlier studies on wage rigidity in Germany (Pfeiffer, 2003) suggests that wage flexibility has always been higher in economic downturns and lower in economic upturns. Since the economic downturn in Germany started around 2001/2002, after the internet boom, the evidence of rising wage inequality discussed in this paper may be temporary in nature. However this seems to be not very plausible, given the world wide evidence of rising wage inequality and the trade orientation of the German economy.

The rest of the paper is organized as follows: Section 2 introduces the econometric framework to decompose wage development into observable changes in the composition of the work force, changes in prices and residual wage inequality. Section 3 describes the data. Section 4 discusses descriptive evidence on the evolution of wages and inequality in West Germany between 1984 and 2004. Section 5 presents the econometric findings for West Germany. Section 6 discusses descriptive and econometric evidence on the evolution of wages and wage inequality in East Germany between 1994 and 2004 and in comparison to West Germany. Section 7 provides a summary of interpretations and concludes.

\section{Decomposition method}

To investigate empirical reasons for increasing wage inequality the decomposition method by Juhn et al. (1993) is employed. The idea is to divide changes in wage inequality into three basic components. First, changes in the prices for observable characteristics of workers, second, changes in the composition of the workforce and, third, unobserved or residual wage inequality. It is assumed that the log of wages depends linearly on a vector of observed characteristics, and an unobserved term:

$$
\text { (1) } \quad Y_{i t}=X_{i t} \beta_{t}+u_{i t}
$$

$Y_{i t}$ is the real $\log$ hourly wage of individual $i$ in year $t, X_{i t}$ is a vector of individual characteristics that defines the observed composition of the workforce, $\beta_{t}$ is a vector of "prices" for these observable characteristics in year $t$ and $u_{i t}$ is the residual. Juhn et al. $(1993,425)$ define $u_{i t}$ to contain two components: "an individual's percentile in the residual distribution, $\theta_{i t}$, and the distribution function of the wage equation residuals, $F_{t}(.) \cdot F_{t}^{-1}\left(\cdot \mid X_{i t}\right)$ is the inverse cumulative residual distribution for workers with characteristics $X_{i t}$ in year $t$ ”:

$$
u_{i t}=F_{t}^{-1}\left(\theta_{i t} \mid X_{i t}\right)
$$

To study changes in wage inequality a base year needs to be defined. In this study two base years are chosen, 1984 or 1994, for reasons explained in chapter 3. The 
vector of prices $\bar{\beta}$ and the residual distribution $\bar{F}^{-1}($.) are fixed to the values of the base year. To decompose the wages, equation (1) is transformed into equation (3):

$$
Y_{i t}=X_{i t} \bar{\beta}+X_{i t}\left(\beta_{t}-\bar{\beta}\right)+\bar{F}^{-1}\left(\theta_{i t} \mid X_{i t}\right)+\left[F_{t}^{-1}\left(\theta_{i t} \mid X_{i t}\right)-\bar{F}^{-1}\left(\theta_{i t} \mid X_{i t}\right)\right]
$$

The desired results are derived in a three step procedure. In the first step, prices and the residual distribution are fixed to the estimated value of the chosen base year. Only changes of the composition of the workforce are allowed:

$$
Y_{i t}^{1}=X_{i t} \bar{\beta}+\bar{F}^{-1}\left(\theta_{i t} \mid X_{i t}\right)
$$

In the second step changing prices of the observables are estimated by fixing the common distribution of the residuals:

$$
\text { (5) } \quad Y_{i t}^{2}=X_{i t} \beta_{t}+\bar{F}^{-1}\left(\theta_{i t} \mid X_{i t}\right)
$$

The third step allows for workforce composition, price and residual changes and equation (1) is estimated:

$$
Y_{i t}^{3}=X_{i t} \beta_{t}+F_{t}^{-1}\left(\theta_{i t} \mid X_{i t}\right)=X_{i t} \beta_{t}+u_{i t}=Y_{i t}
$$

The three steps deliver three predictions of real wage, denoted $Y_{t}^{1}, Y_{t}^{2}$ and $Y_{t}^{3}$, from which decomposition results are obtained. $Y_{t+1}^{1}-Y_{t}^{1}$ results from changes in the composition of the workforce, $Y_{t+1}^{2}-Y_{t}^{2}-\left(Y_{t+1}^{1}-Y_{t}^{1}\right)$ from changes in the prices for observables, while $Y_{t+1}^{3}-Y_{t}^{3}-\left(Y_{t+1}^{1}-Y_{t}^{1}\right)-\left(Y_{t+1}^{2}-Y_{t}^{2}\right)$ is the residual wage inequality, due to changes in the price or composition of unobservables. These latter changes might be the consequences of a revaluation of unobservable characteristics, like intelligence, motivation, self-discipline, social skills or the like. To correctly estimate composite, price and residual effects, in principle the relevant variables should be observed, which as a rule cannot be achieved in real data. Without the full set of relevant variables it may be difficult to distinguish between correlation and causality (in the context of wage inequality see Taber, 2001 among others).

\section{Data}

For the purpose of the analyses two samples from the 21 waves of the German Socio-Economic Panel (GSOEP ${ }^{4}$ ) from 1984 to 2004 have been drawn, both separately for West and for East Germany. ${ }^{5}$ This section concentrates on the samples for West Germany, and section 6 looks at the samples for East Germany.

\footnotetext{
${ }^{4}$ See Haisken-DeNew and Frick (2005); if weights are employed, these are the cross section individual weights.

${ }^{5}$ A comparison with a different data source indicates that our results are similar. The quarterly
} 
First, a full sample has been drawn containing all workers aged 16 to 65 years including the self-employed. ${ }^{6}$ All observations with missing information on variables are dropped. Finally, wages are trimmed by the two percent highest and lowest observations on hourly wages. Through these restrictions, more than half of the observations in the GSOEP are lost, mostly persons that are not participating in the workforce (see Table 1 for number of observations). Second, a restricted sample contains only prime age dependent male workers, aged between 25 and 55. The number of observations in the restricted sample reduces to $45 \%$ of the full sample of all workers (see Table 1). This sample is chosen, on the one hand, to facilitate comparison with previous studies that usually exclude the self-employed or concentrate on specific populations of workers. ${ }^{7}$ On the other hand, it allows an investigation of the question whether wage inequality has also risen in the sample of persons with the highest attachment to the labour market that is prime age dependent males.

The variable real gross hourly wage is obtained for all workers including the selfemployed by division of last month salary by last month's work hours. ${ }^{8}$ Table 1 summarizes the development of real wages and hours worked in Germany for the full and the restricted sample. The mean of real wages is rising throughout the observation period, while hours worked are continuously decreasing in the full sample, and roughly constant in the restricted sample of prime age dependent male workers.

The vector of observables contains formal educational qualification, tenure, potential experience, gender (female), self-employment and nationality (foreigner) of workers. The education system in Germany is characterized by school attendance at age 6 for four years to elementary school (primary sector). Then students have the

wage survey of the German Federal Statistical Office (see Statistisches Jahrbuch 1995, 2005) contains three groups of blue collar workers: group 3 consists of unskilled workers and group 1 of skilled workers (Facharbeiter, Meister), and five groups of white collar workers: group 3 consists of skilled workers and group 5 of unskilled workers. Between 1994 and 2004 the wage gap of male blue collar workers from manufacturing between the skilled and unskilled increased from 26.5\% in 1994 to 33.3\% 2004 in West Germany and from 19.5\% to 29.4\% in East Germany. Between 1994 and 2004 the wage gap of male white collar workers from manufacturing between the skilled and unskilled increased from 53.5\% in 1995 to 62.6\% 2004 in West Germany and from 40.2 to 63.6 percent in East Germany. For females the values are very similar.

${ }^{6}$ Samples 4 and 7 of the GSOEP have been omitted. Sample 4 concentrates on immigrants to West Germany between 1984 and 1993. Sample 7, which is available only for 2002, 2003 and 2004, is an expansion of the GSOEP, concentrated among high wage earners. Several tests to check the sensitivity of the selected sample have been performed. Inclusion of sample 4 does not alter our findings. So sample 4 is excluded, because there is a comparison problem between educational qualifications obtained abroad and in Germany. In addition, the relevance of using sample 6, the extension of observations since 2000, has been checked. However, it made no difference if sample 6 is included or not. So sample 6 is included to exploit the number of observations in the GSOEP.

7 See the introduction and Table A1 in the appendix.

${ }^{8}$ All wages are deflated with the Consumer Price Index for Germany, base year 2000, taken from Statistisches Bundesamt (2005). 
choice between three types of secondary education: 5 years "Hauptschule", 6 years "Realschule" or 9 years "Gymnasium". The "Abitur" obtained at the "Gymnasium" qualifies students to attend "Fachhochschule" or university. Most students choose vocational training after secondary education where they obtain training for tasks and skills required by the labour market. ${ }^{9}$

In the empirical analysis formal education is also divided into six categories:

- Persons without a school qualification and without vocational training,

- Persons with a school qualification but without vocational training,

- Persons with a medium school qualification (without "Abitur”) and with vocational training,

- Persons with highest school qualification (“Abitur”) and with vocational training, also persons with "Beamte, Handelsschule, Techniker",

- Persons with a degree from a "Fachhochschule",

- Persons with a degree from a university.

Table A2 in the appendix summarizes the educational composition of the samples selected from the GSOEP. The share of workers with low educational attainment ${ }^{10}$ increased at the beginning of the 1990s and decreased afterwards. The share of highly educated workers ${ }^{11}$ doubled between 1984 and 2004. Prime age dependent male workers are by and large better educated compared to workers in the overall sample. For the later econometric analysis tenure is divided into thirteen ${ }^{12}$, potential experience into seventeen categories ${ }^{13}$, to allow for non-linearities in the wage determination process. Table A3 in the appendix summarizes the mean of the observables used for explaining the evolution of wage inequality. For the purpose of Table A3, education, tenure and potential experience ${ }^{14}$ are all measured in years ${ }^{15}$. The average duration of years of schooling has risen by 0.9 years in twenty years. Female participation rises from 37 to 47 percent, while the share of foreigners fluctuates around 8 percent. Around 6 percent of the workers in the overall sample are self-employed. Self-employment has been rising continously since 1994.

\footnotetext{
${ }^{9}$ For a detailed description of the German educational system see www.bildungsserver.de.

${ }^{10}$ Without school qualification, without vocational training; school qualification, without vocational training.

11 Degree from "Fachhochschule" or university.

12 The groups range from 0-3 years over 3-6 years to 33-36 years, the group with highest duration are those employees who stayed with the same employer for more than 36 years.

13 The groups range from 0-3 years over 3-6 years to 44-47 years, the highest group here is "more than 47 years".

14 Potential experience is defined as age - years of schooling - 6 .

15 Each educational category is recoded with "normal” years of schooling.
} 
Table 1: Means of Real Wages and Hours

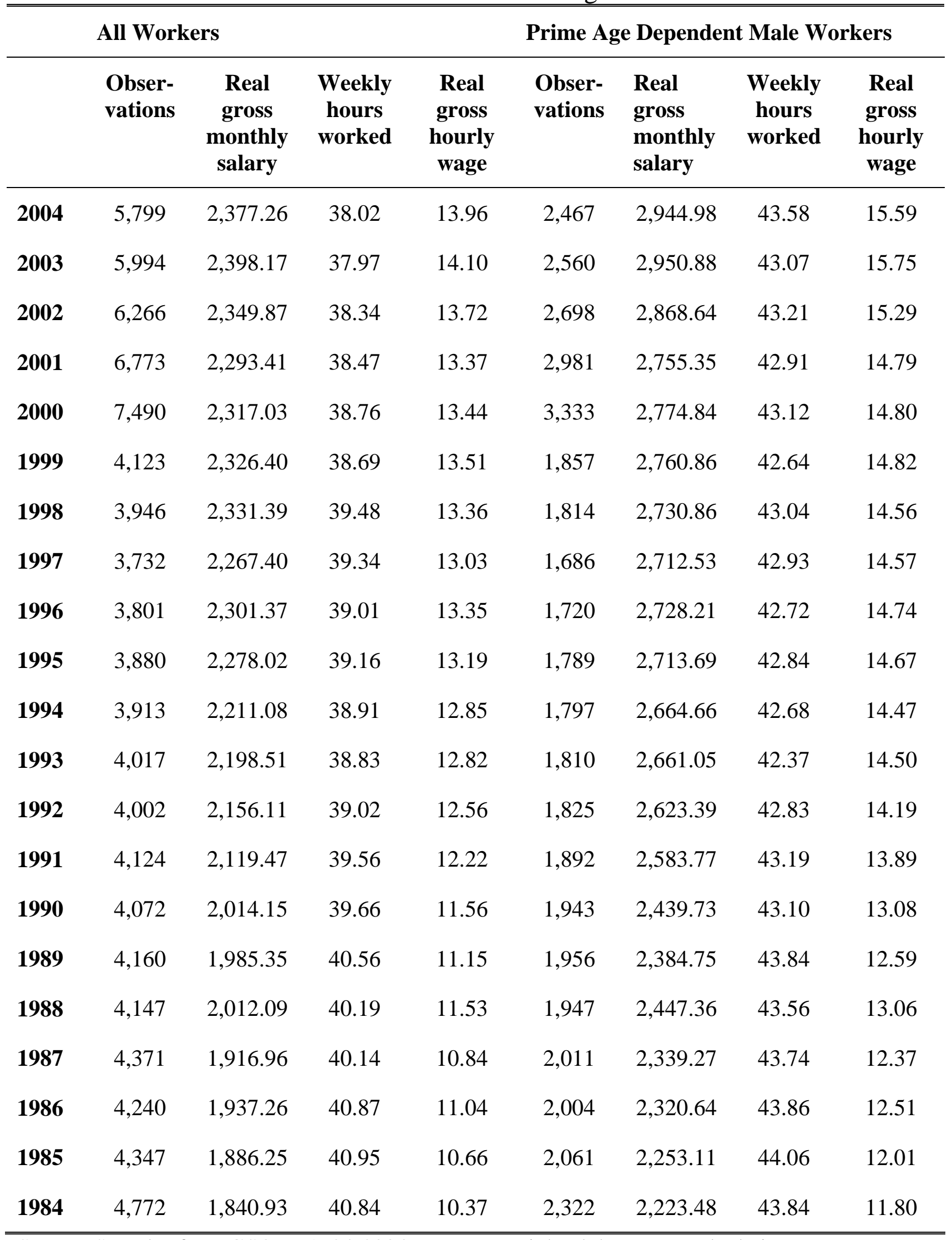

Source: Samples from GSOEP 1984-2004, see text; weighted data; own calculations. 


\section{The Evolution of Wages in West Germany}

This section presents some descriptive findings on the development of wage inequality in the GSOEP samples for West Germany, based partly on graphical illustrations. Table 2 starts with some information on wage inequality as measured by the quotient between the $90^{\text {th }}$ to $10^{\text {th }}$ percentiles in the data. In the full sample the $90^{\text {th }}$ to $10^{\text {th }}$ percentile was 2.59 in 1984, 2.47 in 1994, indicating wage compression, and 3.01 in 2004, indicating rising inequality. This difference is highly significant, as the 95 percent confidence interval shows (Table 2, in brackets). Compared to the full sample wage inequality is lower for females, for foreigners and for prime age dependent male workers, although the increase in rising wage inequality is also present. Wage inequality is highest for self-employed workers, although the numbers do not indicate a clear tendency of wage inequality over the period of observation.

Wage inequality is higher for workers with low compared to high tenure for both samples. The definition of high and low tenure is explained below. For the group of workers with low tenure the tendency of rising wage inequality since 1994 is strongest. The $90^{\text {th }}$ to $10^{\text {th }}$ percentile was 2.18 in 1994 and 2.87 in 2004 for prime age dependent male workers. The difference is significant.

Figure 3 shows wage distributions of workers from the overall and the restricted samples for the years 1984, 1994 and 2004. For 1984 and, to some degree, for 1994 the figure indicates the well-known compressed distribution that is skewed to the right and shaped like a log-normal distribution. The 2004 figure, however, shows more dispersion and more symmetry. Apparently, compared to 1994, more workers earn very low and more workers earn very high wages.

A comparison between the percentiles of the wage distribution 1994 and 2004 reveals that real wages below the $25^{\text {th }}$ percentile decreased, and that wages above the median grew at roughly similar rates. This suggests that inequality is rising mainly below the median, confirming Möller (2005). The result is furthermore in line with findings by Juhn et al. (1993) for the US in the 1980s. The picture somewhat differs for the sample of prime age dependent males (see Figure 4). In this group only real wages below the $10^{\text {th }}$ percentile decreased and wage growth was especially pronounced between the $50^{\text {th }}$ and the $80^{\text {th }}$ percentiles. For self-employed workers wage growth was more diverse at all percentiles. Foreigners experienced a significant rise in inequality, a result which confirms Riphahn (2003).

To shed some light on the evolution of wage inequality along the skill dimensions in our data, education, potential experience and tenure are each divided into two groups. For these two groups wage growth between 1994 and 2004 for 20 percentiles is compared. "High educated" are workers with a degree from a "Fachhochschule" or university, "low educated" the others; "high experience" are workers with more than 20 years of potential experience (the median of potential experience 
in the sample), "low experience" the others. "High tenure" are workers with more than 7 years of tenure (the median of tenure in the sample), "low tenure" the others. Table 2 suggests that in the sample of (low) educated workers wage inequality increased. In the sample of high educated workers the numbers indicate no clear tendency. The differences in overall wage inequality between low and high educated workers are rather small, especially in 2004.

Table 2: Wage Inequality in West Germany: $90^{\text {th }}$ to $10^{\text {th }}$ Wage Percentiles

\begin{tabular}{|c|c|c|c|c|c|c|}
\hline & \multicolumn{3}{|c|}{ All Workers } & \multicolumn{3}{|c|}{$\begin{array}{l}\text { Prime Age Dependent Male } \\
\text { Workers }\end{array}$} \\
\hline & 1984 & 1994 & 2004 & 1984 & 1994 & 2004 \\
\hline All & $\begin{array}{c}2.59 \\
(2.52-2.67)\end{array}$ & $\begin{array}{c}2.47 \\
(2.39-2.54)\end{array}$ & $\begin{array}{c}3.01 \\
(2.94-3.07)\end{array}$ & $\begin{array}{c}2.14 \\
(2.07-2.22)\end{array}$ & $\begin{array}{c}2.11 \\
(2.04-2.18)\end{array}$ & $\begin{array}{c}2.52 \\
(2.40-2.63)\end{array}$ \\
\hline Females & $\begin{array}{c}2.46 \\
(2.32-2.60)\end{array}$ & $\begin{array}{c}2.37 \\
(2.28-2.45)\end{array}$ & $\begin{array}{c}2.95 \\
(2.76-3.14)\end{array}$ & · & · & $\cdot$ \\
\hline Foreigners & $\begin{array}{c}2.13 \\
(2.03-2.23)\end{array}$ & $\begin{array}{c}2.07 \\
(1.95-2.19)\end{array}$ & $\begin{array}{c}2.63 \\
(2.43-2.82)\end{array}$ & $\begin{array}{c}1.74 \\
(1.64-1.85)\end{array}$ & $\begin{array}{c}1.83 \\
(1.71-1.95)\end{array}$ & $\begin{array}{c}2.29 \\
(2.00-2.57)\end{array}$ \\
\hline Self-employed & $\begin{array}{c}5.25 \\
(4.51-5.99)\end{array}$ & $\begin{array}{c}3.63 \\
(3.21-4.06)\end{array}$ & $\begin{array}{c}4.51 \\
(4.01-5.02)\end{array}$ & $\cdot$ & $\cdot$ & $\cdot$ \\
\hline High educated & $\begin{array}{c}2.63 \\
(2.34-2.93)\end{array}$ & $\begin{array}{c}2.34 \\
(2.15-2.53)\end{array}$ & $\begin{array}{c}2.68 \\
(2.47-2.89)\end{array}$ & $\begin{array}{c}2.38 \\
(2.03-2.73)\end{array}$ & $\begin{array}{c}2.02 \\
(1.84-2.21)\end{array}$ & $\begin{array}{c}2.10 \\
(1.96-2.23)\end{array}$ \\
\hline Low educated & $\begin{array}{c}2.40 \\
(2.33-2.47)\end{array}$ & $\begin{array}{c}2.27 \\
(2.20-2.34)\end{array}$ & $\begin{array}{c}2.81 \\
(2.73-2.90)\end{array}$ & $\begin{array}{c}1.95 \\
(1.89-2.01)\end{array}$ & $\begin{array}{c}1.97 \\
(1.91-2.03)\end{array}$ & $\begin{array}{c}2.34 \\
(2.22-2.46)\end{array}$ \\
\hline High tenure & $\begin{array}{c}2.39 \\
(2.29-2.48)\end{array}$ & $\begin{array}{c}2.26 \\
(2.16-2.36)\end{array}$ & $\begin{array}{c}2.67 \\
(2.58-2.75)\end{array}$ & $\begin{array}{c}2.07 \\
(2.00-2.14)\end{array}$ & $\begin{array}{c}1.99 \\
(1.92-2.05)\end{array}$ & $\begin{array}{c}2.25 \\
(2.17-2.33)\end{array}$ \\
\hline Low tenure & $\begin{array}{c}2.57 \\
(2.48-2.66)\end{array}$ & $\begin{array}{c}2.46 \\
(2.33-2.58)\end{array}$ & $\begin{array}{c}3.09 \\
(2.92-3.26)\end{array}$ & $\begin{array}{c}2.13 \\
(2.02-2.25)\end{array}$ & $\begin{array}{c}2.18 \\
(2.06-2.29)\end{array}$ & $\begin{array}{c}2.87 \\
(2.66-3.07)\end{array}$ \\
\hline $\begin{array}{l}\text { High potential } \\
\text { experience }\end{array}$ & $\begin{array}{c}2.56 \\
(2.45-2.67)\end{array}$ & $\begin{array}{c}2.56 \\
(2.45-2.66)\end{array}$ & $\begin{array}{c}3.12 \\
(3.02-3.22)\end{array}$ & $\begin{array}{c}2.07 \\
(1.99-2.16)\end{array}$ & $\begin{array}{c}2.01 \\
(1.93-2.10)\end{array}$ & $\begin{array}{c}2.37 \\
(2.28-2.45)\end{array}$ \\
\hline $\begin{array}{l}\text { Low potential } \\
\text { experience }\end{array}$ & $\begin{array}{c}2.54 \\
(2.40-2.68)\end{array}$ & $\begin{array}{c}2.33 \\
(2.24-2.43)\end{array}$ & $\begin{array}{c}2.92 \\
(2.80-3.05)\end{array}$ & $\begin{array}{c}2.08 \\
(1.97-2.19)\end{array}$ & $\begin{array}{c}2.10 \\
(2.02-2.17)\end{array}$ & $\begin{array}{c}2.63 \\
(2.43-2.84)\end{array}$ \\
\hline
\end{tabular}

Source: Samples from GSOEP 1984-2004, see text; in brackets: 95\% confidence interval, calculated by bootstrapping (1,000 replications), own calculations. 
Figure 3: The Evolution of Wages in West Germany 1984, 1994, 2004
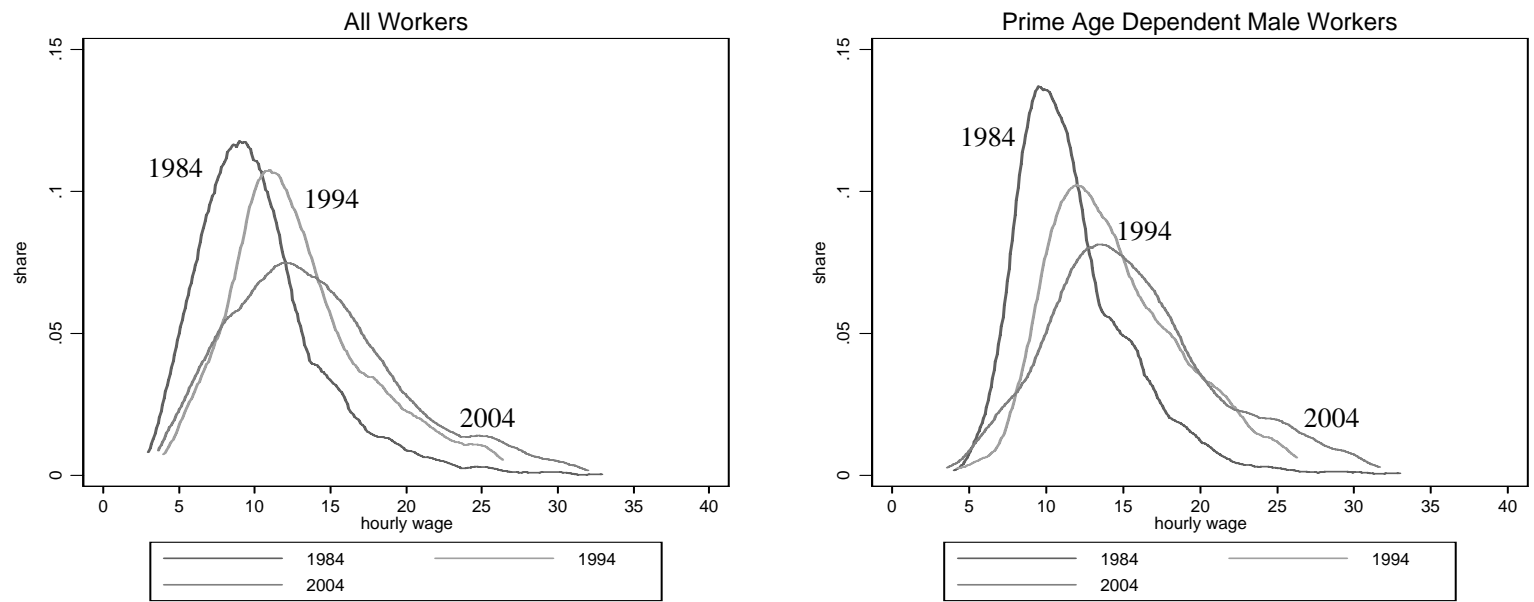

Source: GSOEP (for the samples see Chapter 3), weighted data; own calculation.

Figure 4: Wage Growth in 20 Percentiles, West Germany 1994-2004
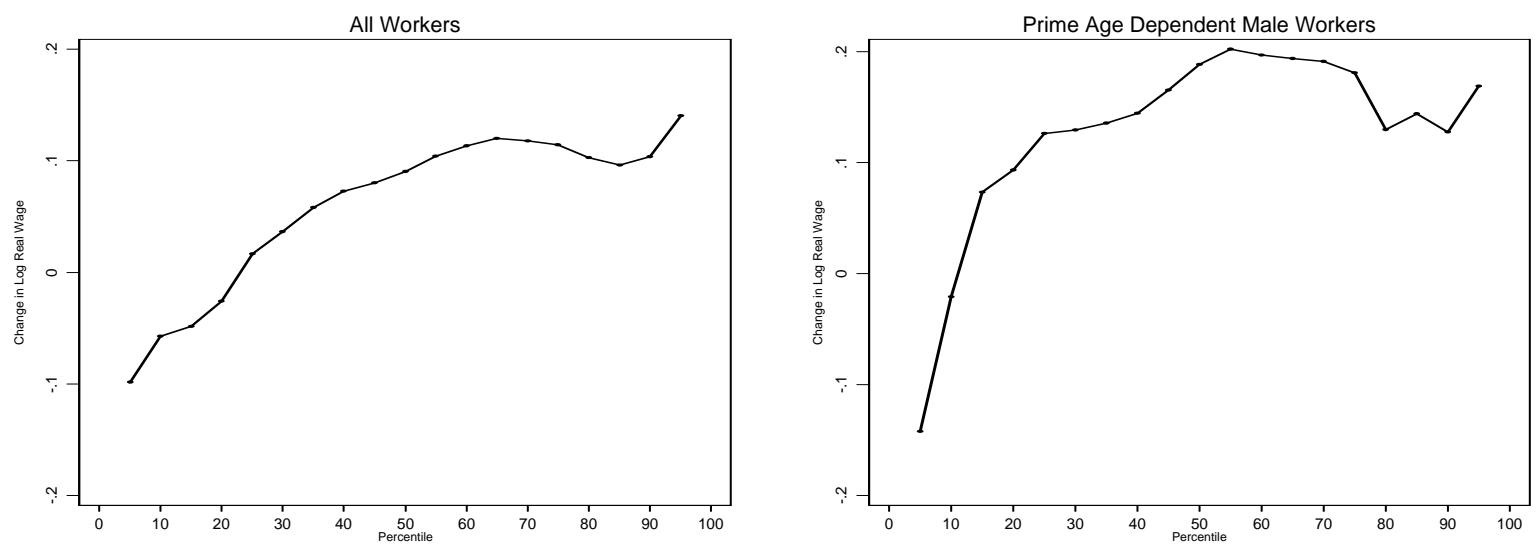

Source: GSOEP (for the samples see Chapter 3); weighted data; own calculation.

Figure 5 suggests that rising wage inequality is evident also in the group of highly educated workers, when one takes all percentiles into account. Indeed within this group of workers our measures indicate a rise in wage dispersion that is however restricted to specific percentiles. Real wages below the $40^{\text {th }}$ percentiles decreased, and most of the decrease had already occurred between 1994 and 1998 (a result that is not visible from Figure 4). This finding confirms Fitzenberger (1999), who argues that rising wage inequality in qualification skill groups occurred in the 1990s and also corroborates findings by Juhn et al. (1993) for the US in the 1980s. In the group of low skilled workers rising wage inequality occurs primarily in the lower part of the wage distribution.

Figure 6 suggests some differences in the wage growth between workers with high and low experience. Workers with "low experience" suffered wage decreases up to the $30^{\text {th }}$ percentile, while this was the case only up to the $20^{\text {th }}$ percentile in the group of workers with "high experience". 
Figure 5: Wage Growth in 20 Percentiles, West Germany, Low and High Educated
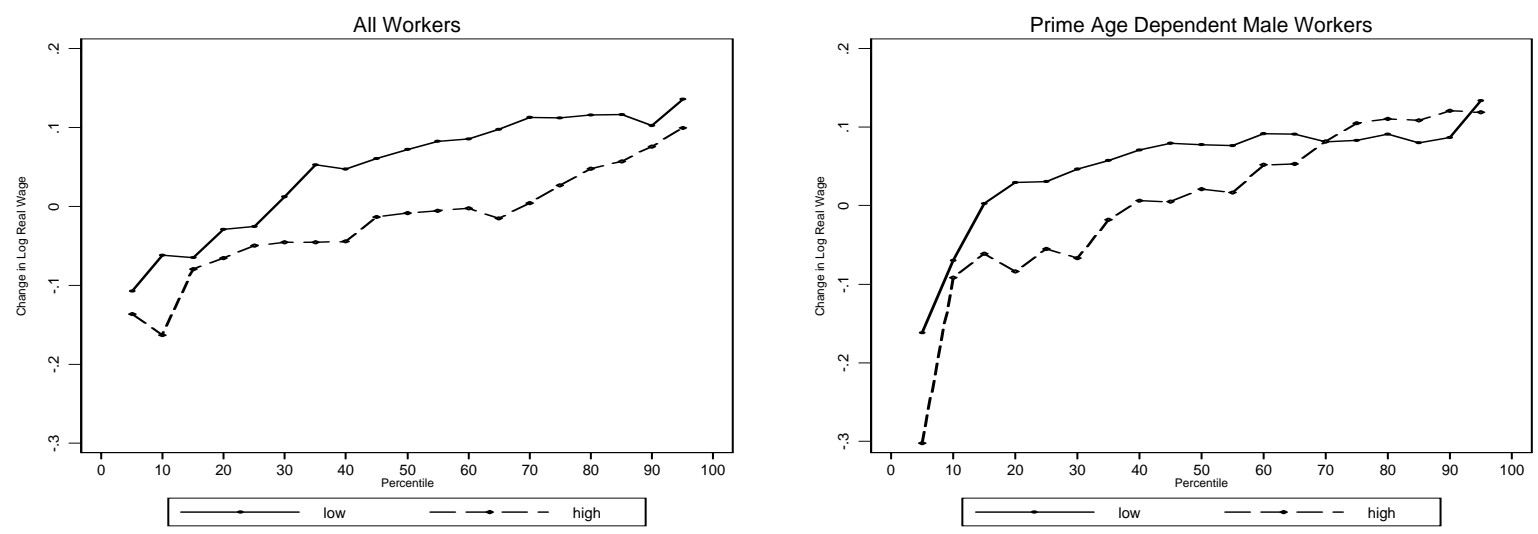

Source: GSOEP 1994-2004 (for the samples see Chapter 3); weighted data; own calculation.

Figure 6: Wage Growth in 20 Percentiles, West Germany, Low and High Potential Experience 1994-2004
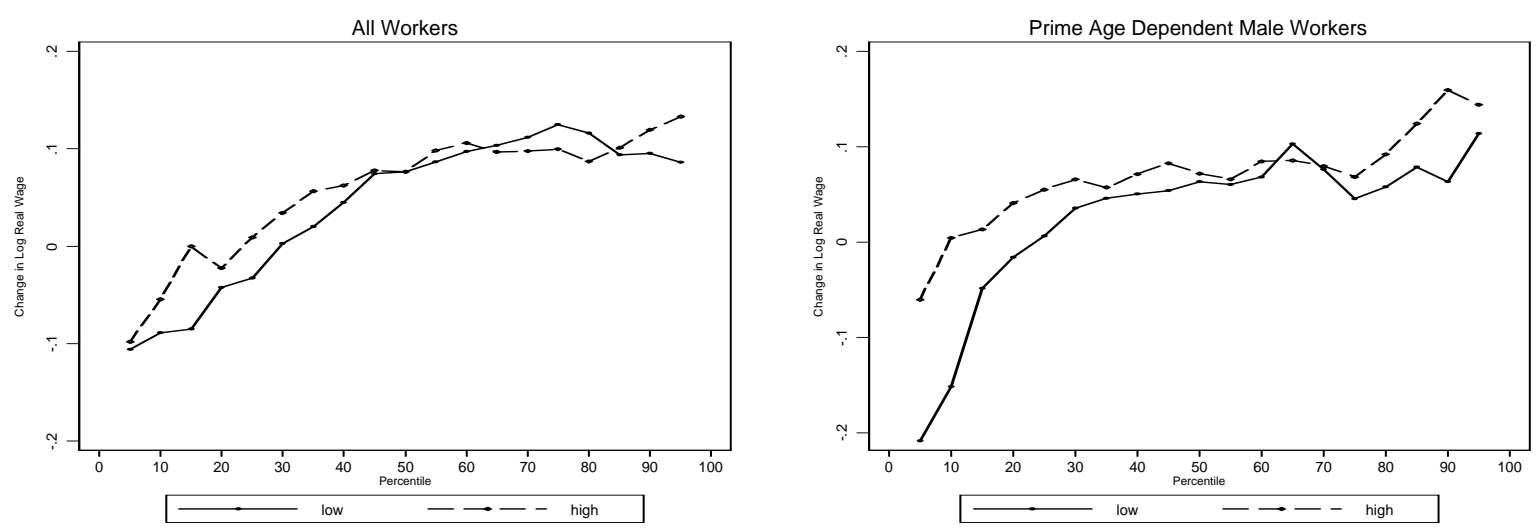

Source: GSOEP 1994-2004 (for the samples see Chapter 3); weighted data; own calculation.

Interestingly however, there are larger differences in wage growth for workers with low and for workers with high tenure. This is visible in Figure 7 for both samples and even more pronounced in the sample of prime age dependent male workers. Between 1994 and 2004 wage growth of the "high tenure" group exceeds wage growth of the "low tenure" group in all percentiles below the $60^{\text {th }}$ percentiles of the wage distribution. The differences are quantitatively large and practically there is no percentile with a wage decrease for workers from the group with "high tenure". In comparison, real wages of workers with low tenure decreased below the $40^{\text {th }}$ percentile of the wage distribution. According to these results tenure seems to be an important dimension of wage inequality and wage flexibility, which confirms earlier microeconometric findings on the wage sweep-up by Pfeiffer (2003) and Gernandt and Pfeiffer (2006). Wage growth in the group of workers with "low tenure" shows much more inequality and dispersion compared to the "high tenure" group.

This result suggests that the adjustment of wages to labour market conditions takes place primarily among entrants into the labour market. In the German labour market 
the estimated share of entrants is around eleven percent in a cross section (Gernandt and Pfeiffer, 2006). In the group of workers with high tenure, adjustment to the market conditions for labour and goods takes place primarily through reduction of employment or hours, not through a reduction of wages (Pfeiffer 2003).

Figure 7: Wage Growth in 20 Percentiles, West Germany, Low and High Tenure 1994-2004
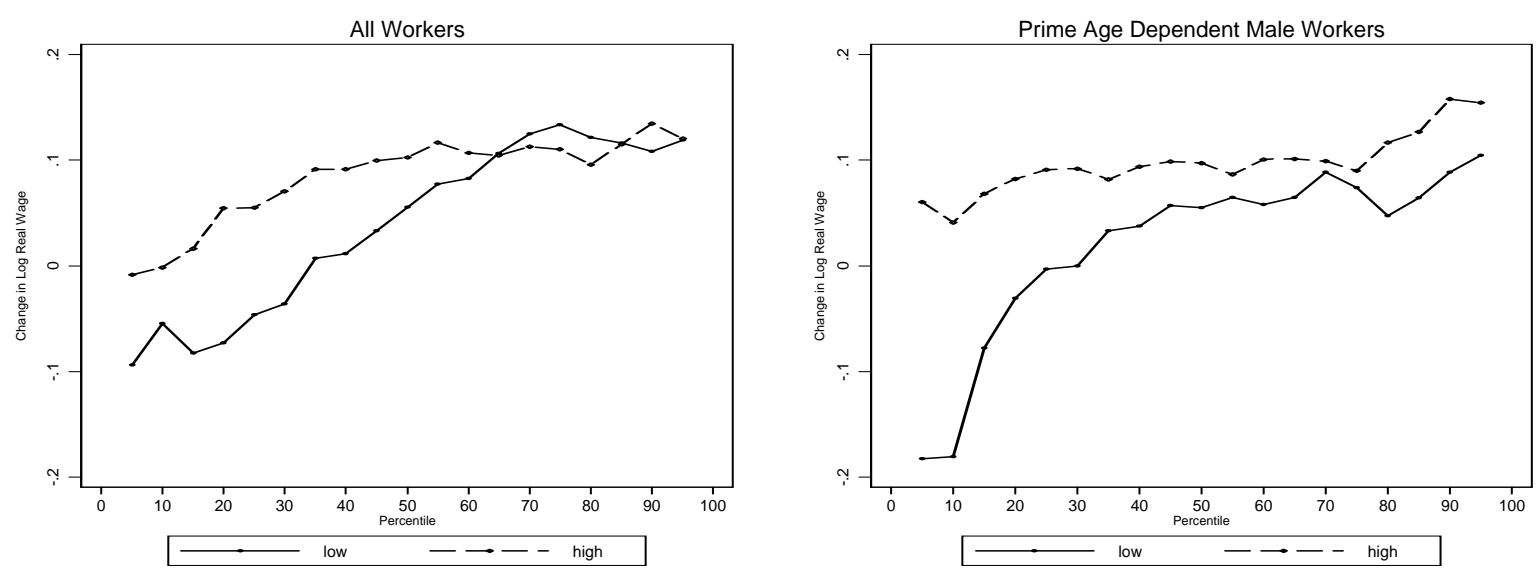

Source: GSOEP 1994-2004 (for the samples see Chapter 3); weighted data; own calculation.

\section{Econometric Evidence for West Germany}

This section discusses the results from the econometric decomposition method, explained in section 2. Changes in wage inequality are divided into three components: changes in the prices for observable characteristics, changes in the composition of the workforce and unobserved or residual wage inequality. The vector of observables employed from the GSOEP contains six formal educational qualification categories, thirteen tenure categories, seventeen potential experience categories, gender (female), self-employment and nationality (foreigner) of workers, as has been explained in section 3 above. The econometric analysis concentrates on the explanation of the $90^{\text {th }}$ to $10^{\text {th }}$ as well as its two sub-groups, the $90^{\text {th }}$ to $50^{\text {th }}$ and the $50^{\text {th }}$ to $10^{\text {th }}$ differential. The sub-group effects summarize to produce the overall effect.

The empirical findings for the West German samples and for some sub-samples along the skill dimensions are reported in Tables 3 and 4 . To read these tables, look, for example, at the first row in Table 3: The wage dispersion between the $90^{\text {th }}$ and the $10^{\text {th }}$ percentile (column one) increased in total (column two) by 0.146 log points or 15.7 percent $\left(\left(e^{0.146}-1\right) * 100=15.7\right)$. The total wage growth is decomposed into a quantity effect (column 3), 0.045 log points, a price effect of -0.003 log points (column 4), and due to unobserved, residual factors, which amount to 0.104 log points, or 71 percent of the total effect. Prices for this sample have a negative (although very small) effect. Thus price changes reduced wage inequality - here by a very small amount. To summarize the findings of row 1 in Table 3: If the workforce in 
2004 had had the same observable composition as the workforce in 1984, the wage dispersion ceteris paribus would have increased by 0.101 log points (total - quantity effect). This was by and large a result of a rise in residual wage inequality.

The econometric decomposition, first, confirms some of the descriptive findings on wage inequality from section 3 and, second, helps to clarify the role of the chosen observed skill characteristic as explanatory factors for rising inequality. The results are partly in line with findings of rising wage inequality in the US from the years 1979 to 1988 , where the 90 to $10^{\text {th }}$ percentile difference increased by 0.208 log points, $42 \%$ occurred above the median and 58\% below the median (Juhn et al., 1993). The findings for the full sample and the restricted sample of prime age dependent male workers can be summarized as follows, Table 3:

- Although over the whole period wage inequality increased significantly, the increase happened in the period from 1994 and 2004. For the period from 1984 and 1994 our findings confirm the often cited stability of German wages, as has been discussed in section 1 .

- In the full sample there seems to appear an asymmetry in the increase of wage inequality between 1994 and 2004: The increase is quantitatively more pronounced in the lower part of the wage distribution (below the median), although it also exists in the upper part (above the median). This is in line with Juhn et al. (1993) and Möller (2005), whose findings are based on dependent workers only.

- The econometric results differ between the full sample of all workers, including women and the self-employed, and the restricted sample of prime age dependent male workers. These differences are quantitatively small, however. In fact, the results for the two samples are more similar than diverse. There was slightly less wage dispersion in the second period in the sample of prime age dependent male workers. Furthermore the rise in wage inequality in the lower part of the wage distribution appears to be higher for male workers compared to females.

- The group of self-employed workers experience a higher degree of wage inequality in all periods. Interestingly however in this group there was a period of significant wage compression around 1994 and no overall tendency to an increase in inequality in the observation period. The rise in self-employment is not responsible for rising inequality. The phenomenon of rising inequality in West Germany is restricted to dependent workers.

- The estimated quantity or composition effects have only a minor impact on the evolution of wages in each decade. Their impact is visible however over the two decades in the overall sample. In the restricted more homogenous sample of prime age dependent males their impact on the evolution of wages can be ignored. 
Table 3: Decomposition Results for West Germany

\begin{tabular}{|c|c|c|c|c|}
\hline \multicolumn{5}{|c|}{ All Workers } \\
\hline Differential & Total & Quantities & Prices & Unobserved \\
\hline \multicolumn{5}{|c|}{ 1984-2004 (base year 1984) } \\
\hline 90-10 & 0.146 & 0.045 & -0.003 & 0.104 \\
\hline $90-50$ & 0.032 & 0.029 & -0.030 & 0.032 \\
\hline $50-10$ & 0.114 & 0.016 & 0.027 & 0.071 \\
\hline \multicolumn{5}{|c|}{ 1984-1994 (base year 1984) } \\
\hline $90-10$ & -0.050 & 0.020 & -0.043 & -0.027 \\
\hline 90-50 & -0.018 & 0.037 & -0.033 & -0.022 \\
\hline $50-10$ & -0.032 & -0.017 & -0.010 & -0.005 \\
\hline \multicolumn{5}{|c|}{ 1994-2004 (base year 1994) } \\
\hline $90-10$ & 0.196 & 0.007 & 0.055 & 0.134 \\
\hline 90-50 & 0.050 & -0.028 & 0.025 & 0.053 \\
\hline $50-10$ & 0.145 & 0.035 & 0.029 & 0.081 \\
\hline \multicolumn{5}{|c|}{ Prime Age Dependent Male Workers } \\
\hline Differential & Total & Quantities & Prices & Unobserved \\
\hline \multicolumn{5}{|c|}{ 1984-2004 (base year 1984) } \\
\hline 90-10 & 0.153 & 0.023 & 0.030 & 0.100 \\
\hline 90-50 & 0.035 & -0.004 & -0.002 & 0.041 \\
\hline $50-10$ & 0.118 & 0.027 & 0.032 & 0.059 \\
\hline \multicolumn{5}{|c|}{ 1984-1994 (base year 1984) } \\
\hline $90-10$ & -0.016 & 0.030 & -0.022 & -0.024 \\
\hline $90-50$ & -0.025 & 0.015 & -0.021 & -0.019 \\
\hline $50-10$ & 0.009 & 0.015 & -0.001 & -0.005 \\
\hline \multicolumn{5}{|c|}{ 1994-2004 (base year 1994) } \\
\hline $90-10$ & 0.169 & -0.001 & 0.055 & 0.116 \\
\hline $90-50$ & 0.060 & -0.013 & 0.019 & 0.054 \\
\hline $50-10$ & 0.109 & 0.012 & 0.036 & 0.062 \\
\hline
\end{tabular}

Source: GSOEP 1984-2004 (for the samples see section 3; Juhn et al. (1993) decomposition method, own calculations. 
- There occurred some price effects in the period from 1994 to 2004. Price changes for observed characteristics are responsible for one quarter to one third of overall inequality. Their impact is quantitatively more important in the lower part of the wage distribution. These findings seem to be in line with the higher depreciation rates of vocational skills in Germany (see Ludwig and Pfeiffer, 2006) and the rising skill premium (see Acemoglu, 2002, Bellman and Gartner, 2003).

- Changes in unobserved or residual wage inequality are responsible for two thirds to three quarters of the overall rise in wage inequality. Compared to Juhn et al. (1993) residual wage inequality is quantitatively much more important in the samples for West Germany. In their US study, residual wage inequality accounted for about $43 \%$ of overall inequality.

The decomposition method applied to the overall sample and the sample restricted to prime age dependent male workers uncovers some interesting empirical regularities of rising wage inequality in West Germany. Since unobserved heterogeneity accounts for two thirds of the rise in inequality, the findings should be interpreted with care. The estimates could suffer from omitted variables biases and measurement problems. The economic content of the education categories chosen might differ over time and reported hours of works might contain errors, for example. Nevertheless, the analysis is helpful to empirically structure driving forces behind rising inequality. The general trend to rising wage inequality is not the result of rising selfemployment and seems to be specifically concentrated among low skilled workers and entrants.

To investigate the latter issue in more detail the decomposition method is applied to different skill and tenure groups. The results are documented in Table 4, firstly for the six educational groups, secondly for two tenure groups and two potential experience groups. Since the number of observations are low for some of these groups (see section 3 for the data) these findings might be only weakly determined.

The estimated coefficients hint at quantitatively larger positive price effects for low educated workers and entrants (workers with low tenure). These groups of workers suffered from a relatively larger decline in the returns for their observed skills. ${ }^{16}$ One interpretation for this finding is the persistently high unemployment in the observation period with a peak of 10.8 percent in 1997 (9.1 percent in 1994 and 9.4 percent in 2004). Adjustment to the pressure of high unemployment took place primarily through wage decreases in the labour markets for the low educated and for entrants. ${ }^{17}$ Wages for workers with longer years of tenure are more rigid and firms primarily adjust for this group of employees through reductions of hours of work or employment (Pfeiffer, 2003).

\footnotetext{
${ }^{16}$ Also note that wage inequality among university leavers is concentrated in the upper part of the wage distribution, above the median.

${ }^{17}$ For the international evidence compare Blau and Kahn (1996).
} 
Table 4: Decomposition Results for Specific Groups of Workers

\section{a) All Workers}

\begin{tabular}{llccc}
\hline Differential & Total & Quantities & Prices & Unobser \\
\hline \multicolumn{5}{c}{ Education } \\
\hline $\mathbf{5 0 - 1 0}$ & Without school qualification and without vocational training \\
$\mathbf{9 0 - 5 0}$ & 0.418 & 0.010 & 0.393 & 0.015 \\
$\mathbf{5 0 - 1 0}$ & 0.272 & 0.087 & 0.186 & -0.001 \\
& 0.146 & -0.077 & 0.207 & 0.016
\end{tabular}

With school qualification but without vocational training

$\begin{array}{lllll}\mathbf{9 0 - 1 0} & 0.290 & 0.016 & 0.064 & 0.210 \\ \mathbf{9 0 - 5 0} & 0.110 & 0.022 & 0.028 & 0.059 \\ \mathbf{5 0 - 1 0} & 0.180 & -0.006 & 0.036 & 0.151\end{array}$

With medium school qualification (without Abitur) and with vocational training

$\begin{array}{lllll}\mathbf{9 0 - 1 0} & 0.200 & -0.007 & 0.058 & 0.148 \\ \mathbf{9 0 - 5 0} & 0.066 & -0.016 & 0.023 & 0.059 \\ \mathbf{5 0 - 1 0} & 0.134 & 0.009 & 0.035 & 0.089\end{array}$

With highest school qualification (without Abitur) and with vocational training, also

\begin{tabular}{lllll} 
& \multicolumn{4}{c}{ “Beamte, Handeslschule, Techniker” } \\
$\mathbf{9 0 - 1 0}$ & 0.192 & 0.040 & 0.042 & 0.110 \\
$\mathbf{9 0 - 5 0}$ & 0.047 & 0.002 & 0.003 & 0.042 \\
$\mathbf{5 0 - 1 0}$ & 0.145 & 0.038 & 0.038 & 0.069
\end{tabular}

$\begin{array}{lllll}\mathbf{9 0 - 1 0} & 0.123 & 0.087 & -0.098 & 0.133 \\ \mathbf{9 0 - 5 0} & 0.033 & 0.080 & -0.082 & 0.035 \\ \mathbf{5 0 - 1 0} & 0.090 & 0.008 & -0.016 & 0.098\end{array}$

\begin{tabular}{lllll}
$\mathbf{9 0 - 1 0}$ & 0.144 & \multicolumn{5}{c}{ Degree from a university } \\
$\mathbf{9 0 - 5 0}$ & 0.082 & 0.008 & -0.016 & 0.151 \\
$\mathbf{5 0 - 1 0}$ & 0.062 & 0.010 & 0.006 & 0.066 \\
& & -0.002 & -0.022 & 0.085
\end{tabular}

Tenure

\begin{tabular}{lllll}
\hline & \multicolumn{4}{c}{ Low tenure } \\
$\mathbf{9 0 - 1 0}$ & 0.229 & 0.020 & 0.033 & 0.176 \\
$\mathbf{9 0 - 5 0}$ & 0.100 & 0.007 & 0.024 & 0.070 \\
$\mathbf{5 0 - 1 0}$ & 0.129 & 0.013 & 0.009 & 0.107
\end{tabular}




$\begin{array}{lllll}\mathbf{9 0 - 1 0} & 0.158 & 0.009 & \text { High tenure } \\ \mathbf{9 0 - 5 0} & 0.049 & -0.014 & 0.014 & 0.135 \\ \mathbf{5 0 - 1 0} & 0.109 & 0.023 & 0.003 & 0.060 \\ & & 0.010 & 0.075\end{array}$

Potential experience

\begin{tabular}{lcccc}
\hline & \multicolumn{4}{c}{ Low potential experience } \\
$\mathbf{9 0 - 1 0}$ & 0.226 & 0.016 & 0.069 & 0.141 \\
$\mathbf{9 0 - 5 0}$ & 0.060 & -0.025 & 0.032 & 0.053 \\
$\mathbf{5 0 - 1 0}$ & 0.165 & 0.041 & 0.037 & 0.088 \\
& & High potential experience & \\
$\mathbf{9 0 - 1 0}$ & 0.199 & 0.012 & 0.031 & 0.156 \\
$\mathbf{9 0 - 5 0}$ & 0.068 & -0.005 & 0.004 & 0.068 \\
$\mathbf{5 0 - 1 0}$ & 0.131 & 0.016 & 0.027 & 0.088 \\
\hline
\end{tabular}

b) Prime Age Dependent Male Workers

\begin{tabular}{|c|c|c|c|c|}
\hline Differential & Total & Quantities & Prices & Unobserved \\
\hline
\end{tabular}

Education

\begin{tabular}{|c|c|c|c|c|}
\hline & \multicolumn{4}{|c|}{ Without school qualification and without vocational training } \\
\hline 90-10 & 0.365 & 0.088 & 0.212 & 0.065 \\
\hline 90-50 & 0.113 & 0.066 & 0.081 & -0.03 \\
\hline \multirow[t]{2}{*}{$50-10$} & 0.252 & 0.021 & 0.131 & 0.100 \\
\hline & \multicolumn{4}{|c|}{ With school qualification but without vocational training } \\
\hline 90-10 & 0.358 & 0.045 & 0.126 & 0.187 \\
\hline $90-50$ & 0.078 & -0.021 & 0.048 & 0.05 \\
\hline $50-10$ & 0.280 & 0.066 & 0.078 & 0.13 \\
\hline
\end{tabular}

With medium school qualification (without Abitur) and with vocational training
90-10
0.123
$-0.027$
0.044
0.106
90-50
0.040
$-0.015$
0.007
0.049
50-10
0.083
$-0.012$
0.037
0.058

With highest school qualification (without Abitur) and with vocational training, also "Beamte. Handeslschule. Techniker"

$\begin{array}{lllll}\mathbf{9 0 - 1 0} & 0.107 & -0.036 & -0.017 & 0.161 \\ \mathbf{9 0 - 5 0} & 0.049 & -0.030 & 0.005 & 0.074 \\ \mathbf{5 0 - 1 0} & 0.058 & -0.006 & -0.023 & 0.086\end{array}$




\begin{tabular}{llccc}
$\mathbf{9 0 - 1 0}$ & -0.039 & \multicolumn{4}{c}{ Degree from a “Fachhochschule” } & 0.099 \\
$\mathbf{9 0 - 5 0}$ & 0.074 & -0.112 & -0.027 & 0.050 \\
$\mathbf{5 0 - 1 0}$ & -0.114 & 0.049 & -0.025 & 0.049 \\
& & -0.160 & -0.002 & \\
$\mathbf{9 0 - 1 0}$ & 0.083 & \multicolumn{2}{c}{ Degree from a university } \\
$\mathbf{9 0 - 5 0}$ & 0.059 & -0.047 & 0.051 & 0.080 \\
$\mathbf{5 0 - 1 0}$ & 0.024 & -0.007 & 0.007 & 0.059 \\
& & -0.041 & 0.044 & 0.021
\end{tabular}

Tenure

\begin{tabular}{lcccc}
\hline \multicolumn{5}{c}{ Low tenure } \\
$\mathbf{9 0 - 1 0}$ & 0.276 & 0.052 & 0.108 & 0.116 \\
$\mathbf{9 0 - 5 0}$ & 0.054 & -0.006 & 0.051 & 0.010 \\
$\mathbf{5 0 - 1 0}$ & 0.222 & 0.058 & 0.058 & 0.106 \\
& \multicolumn{4}{c}{ High tenure } \\
$\mathbf{9 0 - 1 0}$ & 0.124 & 0.001 & -0.005 \\
$\mathbf{9 0 - 5 0}$ & 0.041 & -0.020 & 0.001 & 0.128 \\
$\mathbf{5 0 - 1 0}$ & 0.084 & 0.021 & -0.006 & 0.060 \\
& \multicolumn{5}{c}{ Potential experience } \\
\hline $\mathbf{9 0 - 1 0}$ & 0.225 & Low potential experience \\
$\mathbf{9 0 - 5 0}$ & 0.083 & 0.049 & 0.062 & 0.114 \\
$\mathbf{5 0 - 1 0}$ & 0.142 & -0.002 & 0.027 & 0.058 \\
& & 0.051 & 0.035 & 0.056 \\
$\mathbf{9 0 - 1 0}$ & 0.163 & High potential experience & -0.004 \\
$\mathbf{9 0 - 5 0}$ & 0.060 & 0.040 & 0.001 & 0.127 \\
$\mathbf{5 0 - 1 0}$ & 0.103 & 0.004 & -0.006 & 0.055 \\
\hline 5 & 0.037 & 0.072 \\
\hline
\end{tabular}

Source: GSOEP 1984-2004 (for the samples see section 3; Juhn et al. (1993) decomposition method, own calculations.

Another interpretation hints at non-neutral skilled biased technical change and competition in factor markets. The computer revolution fostered general education and analytical and cognitive non-routine skills (Ludwig and Pfeiffer, 2006; Spitz-Oener, 2006) while vocational education and non-cognitive manual and routine skills lost ground. Competition in factor markets after German reunification (see section 6 below) and the enhancement of the European Union eroded the position of the low skilled in Germany and led to rising wages for some groups of highly skilled workers. A third interpretation points to the role of the educational system. Among others 
Schuetz et al. (2005) argue that the German system of early ability tracking raises inequality in student achievement scores, which may have serious consequences for the wage distribution. Yet another factor might be the rise in active labour market policies in the observation period that might have influenced the search behaviour of workers and firms. ${ }^{18}$ Up to now the relevance of these different explanations for rising inequality is not fully understood. Furthermore, these reasons might have reinforced each other.

\section{The Evolution of Wages and Inequality in East Germany}

In this section, the evolution of wages and wage inequality in East Germany is investigated. Reunification took place in 1990. The transition to a market economy and the resulting adjustment processes in the labour force has prompted intensive research (see Franz and Steiner, 2000, Steiner and Hölzle, 2000 among others). For the purpose of our investigation two samples - one for all workers, one for prime age dependent male workers - have been drawn from the GSOEP 1991 to 2004 (see Table A4 in the appendix). For comparison reasons with West Germany in the econometric analysis, the observation period is restricted to 1994 to 2004, while the descriptive evidence starts from 1991. The sample selection rules, the definition of wages and the skill variables are similar to those for West Germany (see section 3 for details, all tables are available in the appendix).

The discussion concentrates on the main findings and the main differences from West Germany. Figure 8 illustrates the evolution of the wages in East Germany. It indicates that rising wage inequality is present and concentrated in the upper tail of the wage distribution.

Table A4 (appendix) documents that average wages in the East German full sample amounted to 77 percent of the West German full sample (see section 3) and to 73 percent in the sample of prime age dependent male workers in 2004. East German prime age dependent males work on average one hour more than their West German counterparts, while in the full sample the difference is larger, 3.5 hours (in 2004). Full wage convergence did not take place. Table A5 reports some information on wage inequality as measured by the $90^{\text {th }}$ to $10^{\text {th }}$ percentiles in the data, including 95 percent confidence intervals. In the full sample the $90^{\text {th }}$ to $10^{\text {th }}$ percentile was 2.40 in 1994 and 3.02 in 2004. The 95 percent intervals do not overlap, indicating rising inequality. Wage inequality is similar for males and females in the overall sample and in East Germany there is no difference along the tenure dimension. Wage inequality is highest for self-employed workers, as in West Germany.

\footnotetext{
18 For a description of active labour market policies see Franz (2003). For an empirical analysis of wages and employment based on a search theoretic view see Fitzenberger et al. (2003).
} 
Figure 8: The Evolution of Wages in East Germany, 1994, 2004
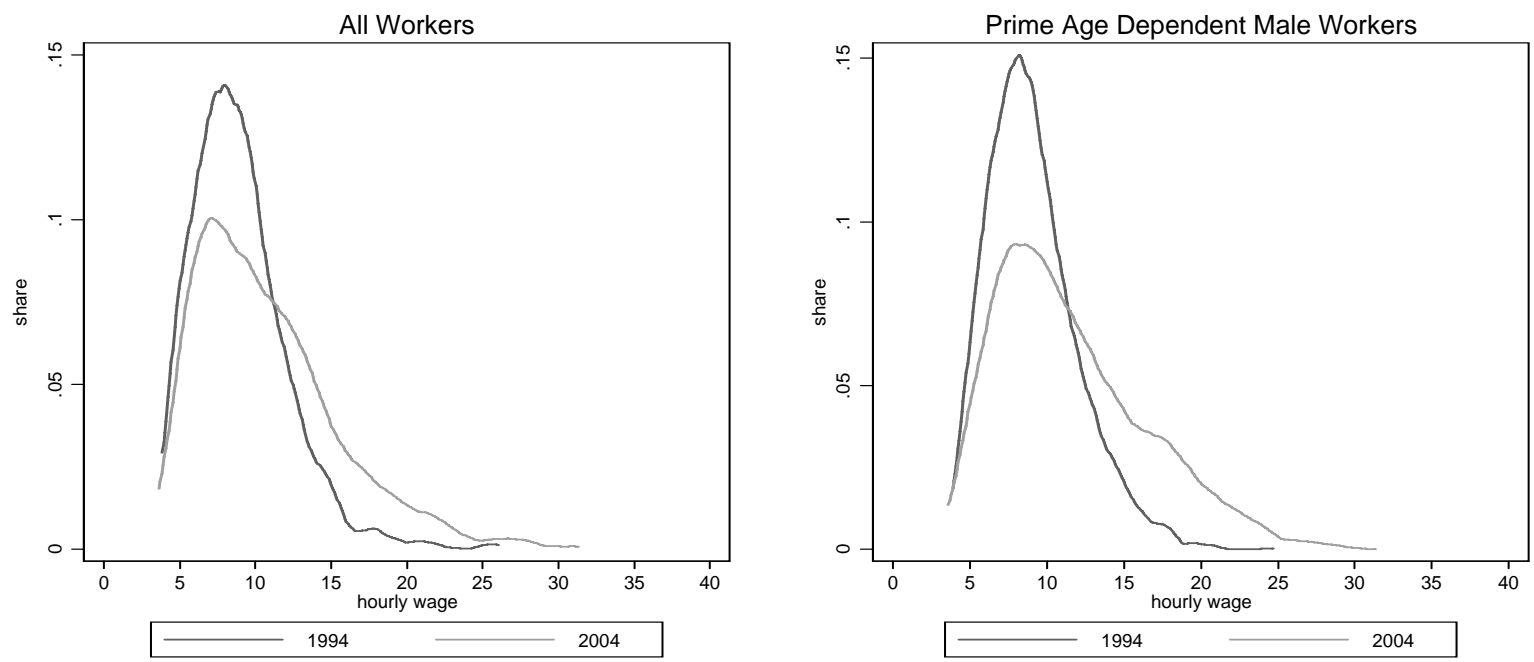

Source: SOEP (for the samples see Chapter 3), weighted data; own calculation.

Table A6 (appendix) summarizes the educational composition of the East German workers. Compared to West Germany there are more workers with high and fewer workers with low education. Table A7 (appendix) summarizes the means for years of education, tenure, potential experience as well as participation rates of females, foreigners and the self-employed. Years of education are higher compared to the West German samples, average tenure is lower since the market economy started in 1990, potential experience is slightly higher, female participation rates are higher (although they are converging in West Germany to East German levels), the share of foreigners is very low and, last but not least, there is a continuous rise in the share of self-employed workers. At the end of the observation period more East compared to West German workers have higher formal education, and foreigners are nearly absent. Unemployment rates are twice as high in East Germany in 2004.

What empirical factors account for the rise in wage inequality in East Germany? What differs between East and West Germany? The results of the econometric decomposition (see Table 5) can be summarized as follows.

- The overall measure ( $90^{\text {th }}$ to $10^{\text {th }}$ differential) indicates a slightly stronger rise in wage inequality in the sample of East compared to West German workers, Table 5. This presumably is a result of transition processes starting in 1990 where convergence still is under way.

- In contrast to the West German findings the larger part of rising inequality occurred in the upper tail of the wage distribution, 60 in comparison to 21 percent in West Germany, Table 5. One reason for this result presumably is the competition for higher wage workers in both parts of Germany and the social transfers according to West German standards. 
- Quantity effects can be neglected in the East German samples. However price effects are significant especially in the upper part of the wage distribution. For prime age dependent male workers price effects are quantitatively more important than residual wage inequality, Table 5. Surprisingly therefore the East German experience with respect to rising wage inequality has more similarities with the US experience for the period 1979 to 1988 (Juhn et al., 1993) than with the West German experience. A possible explanation for this result is the competition for higher wage workers in both parts of Germany, which led to a stronger rise of wages in East Germany to stop migration to West Germany.

- The additional decomposition results for the six educational, two tenure and two experience groups of workers are documented in Tables A8 and A9 in the appendix. The differences in wage inequality between educational groups are less pronounced in East compared to West Germany. In a further contrast to West Germany the tenure effect is opposite. The highest rise in wage inequality occurred in the group of workers with high tenure. In this group residual wage inequality dominates. The competition for higher wage workers in both parts of Germany is presumably one important reason for this result.

Table 5: Decomposition Results East Germany 1994-2004

\begin{tabular}{lllll}
\hline \hline Differential & Total & Quantities & Prices & Unobserved \\
\hline \multicolumn{5}{c}{ All Workers } \\
\hline $\mathbf{9 0 - 1 0}$ & 0.228 & 0.008 & 0.097 & 0.123 \\
$\mathbf{9 0 - 5 0}$ & 0.139 & 0.011 & 0.068 & 0.060 \\
$\mathbf{5 0 - 1 0}$ & 0.090 & -0.003 & 0.029 & 0.064
\end{tabular}

Prime Age Dependent Male Workers

\begin{tabular}{lllll}
\hline $\mathbf{9 0 - 1 0}$ & 0.236 & -0.014 & 0.149 & 0.101 \\
$\mathbf{9 0 - 5 0}$ & 0.145 & -0.022 & 0.140 & 0.027 \\
$\mathbf{5 0 - 1 0}$ & 0.090 & 0.008 & 0.008 & 0.074 \\
\hline \hline
\end{tabular}

Source: GSOEP 1994-2004, for the selection of samples see section 3; own calculations.

\section{Interpretation and Conclusion}

This paper contributes to the ongoing debate on the evolution of wages. Based on the GSOEP 1984 to 2004 the evolution of wage inequality is investigated separately for West Germany between 1984 and 2004, and compared to the evolution of inequality in East Germany between 1994 and 2004. The evolution of wage inequality is studied using the decomposition method proposed by Juhn et al. (1993). 
The paper finds rising wage inequality that started around 1994 in the sample for prime age dependent male workers in both parts of Germany. In the sample for all workers, including women and the self-employed, the trend towards rising wage inequality started around 1996, mainly because there is no rise in wage inequality in the group of self-employed workers. Surprisingly, the evolution of wage inequality in East Germany seems to be more similar (in termini of the overall rise and the relative magnitude of price and composition effects) to the evolution of wage inequality in the United States, as reported by Juhn et al. (1993) for the period 1979 to 1988. If this interpretation is valid the unification shock might have had similar impacts for East German wages than the computer revolution in the United States. Not surprisingly, the paper confirms the well known stability of West German wage distribution for the period 1984 to 1994.

There are some more interesting and economically meaningful results from the econometric decomposition analysis. Rising wage inequality seems to be a general trend in the sense that it is not restricted to groups of workers with specific characteristics, although it is quantitatively more pronounced among West German low skilled workers and workers with low tenure or entrants. The persistently high rates of unemployment led to wage adjustment primarily through wage decreases in the labour markets for entrants (Gernandt and Pfeiffer, 2006). Wages for workers with longer years of tenure are more rigid downward and firms' adjustment for this group of employees takes place through reductions of employment and hours of work (Pfeiffer, 2003).

For West German workers residual wage inequality "explains” roughly two thirds of inequality, with composition and price effects accounting for one third of the rising inequality. Wage inequality primarily occurred in the lower part of the wage distribution. For East German workers residual wage inequality "explains” roughly 40 percent, whereas price accounts for roughly 50 percent of the rising inequality. Wage inequality primarily occurred in the upper part of the wage distribution. These differences presumably are due to the adjustment processes of the two parts of Germany and the resultant intensive competition for (highly) skilled workers.

Prominent additional explanations in the literature on rising wage inequality refer to the non-neutral nature of technical change and a rising demand for cognitive, nonroutine abilities, to globalisation and world-wide factor competition, to decreasing social transfers, decreasing union power (German unions lost 2.8 million of their members between 1994 and 2004), changes in unobserved abilities or rising inequality in abilities resulting from the German educational system of early tracking. Future research could be directed more specifically to these different explanations and reasons for the evolution of wages and inequality. Furthermore the consequences for individual well-being, for employment as well as for the evolution of unemployment need to be investigated in greater detail. 


\section{References}

Acemoglu, D. (2002), Technical Change, Inequality, and the Labor Market, Journal of Economic Literature 40 (1), 7-72.

Autor, D. H., L. F. Katz and M. S. Kearney (2005a), Trends in U.S. Wage Inequality: Re-Assessing the Revisionists, NBER Working Paper 11627.

Autor, D. H., L. F. Katz and M. S. Kearney (2005b), Rising Wage Inequality: The Role of Composition and Prices, NBER Working Paper 11628.

Bellmann, L. and H. Gartner (2003), Fakten zur Entwicklung der qualifikatorischen und sektoralen Lohnstruktur, Mitteilungen aus der Arbeitsmarkt- und Berufsforschung 36, 493-508.

Blau, F. D. and L. M. Kahn (1996), International Differences in Male Wage Inequality: Institutions versus Market Forces, The Journal of Political Economy 104 (4), 791-837.

Budria, S. and P. T. Pereira (2005), Educational Qualifications and Wage Inequality: Evidence for Europe, IZA Discussion Paper 1763, IZA Bonn.

DiNardo, J., N. M. Fortin and T. Lemieux (1996), Labor Market Institutions and the Distribution of Wages, 1973-1992: A Semiparametric Approach, Econometrica 64 (5), 1001-1044.

Fitzenberger, B. (1999), Wages and Employment Across Skill Groups: An Analysis for West Germany, Heidelberg (Physica).

Fitzenberger, B. and W. Franz (2001), Jobs. Jobs? Jobs! Orientierungshilfen für den Weg zu mehr Beschäftigung. In: Franz, W., H. Hesse, H. J. Ramser and M. Stadler, Wirtschaftspolitische Herausforderungen an der Jahrhundertwende, Tübingen, 3-42.

Fitzenberger, B., A. Garloff and K. Kohn (2003), Beschäftigung und Lohnstrukturen nach Qualifikationen und Altersgruppen: Eine empirische Analyse auf Basis der IAB-Beschäftigtenstichprobe, Mitteilungen aus der Arbeitsmarkt- und Berufsforschung 36, 509-524.

Fitzenberger, B., and K. Kohn (2005), Gleicher Lohn für gleiche Arbeit? Zum Zusammenhang zwischen Gewerkschaftsmitgliedschaft und Lohnstruktur in Westdeutschland 1985-1997, Zeitschrift für Arbeitsmarktforschung 38 (2-3), 125146.

Fitzenberger, B., R. Hujer, T. E. MaCurdy and R. Schnabel (2001), Testing for uniform wage trends in West-Germany: A cohort analysis using quantile regressions for censored data, Empirical Economics 26, 41-86.

Franz, W. (2003), Arbeitsmarktökonomik, Berlin (Springer). 
Franz, W. and V. Steiner (2000), Wages in the East German Transition Process: Facts and Explanations, German Economic Review 1 (3), 241-269.

Gernandt, J. and F. Pfeiffer (2006), Einstiegslöhne bei unvollkommenen Arbeitsmärkten, Perspektiven der Wirtschaftspolitk \#2, (in print).

Gottschalk, P. and T. M. Smeeding (1997), Cross-National Comparsions of Earnings and Income Inequality, Journal of Economic Literature 35 (2), 633-687.

Haisken-DeNew, J. and J. R. Frick (2005), DTC Desktop Companion to the German Socio-Economic Panel (SOEP), DIW Berlin.

Juhn,C., K. M. Murphy and B. Pierce (1993), Wage Inequality and the Rise in returns to Skill, The Journal of Political Economy 101 (3), 410-442.

Kahn, L.M. (2000), Wage Inequality, Collective Bargaining, and Relative Employment from 1985 to 1994: Evidence from Fifteen OECD Countries. The Review of Economics and Statistics 82 (4), 564-579.

Katz, L. and D. Autor (1999), Changes in the Wage Structure and Earnings Inequality. In: Ashenfelter, O. and D. Card, Handbook of Labor Economics 3A, 14631555.

Krugman, P. (1994), Past and Prospective Causes of High Unemployment, Economic Review, Federal Reserve Bank of Kansas City, 23-43.

Ludwig, V. and F. Pfeiffer (2006), Abschreibungsraten allgemeiner und beruflicher Ausbildungsraten - empirische Evidenz auf Basis subjektiver Einschätzungen, Jahrbücher für Nationalökonomie und Statistik (in print).

Meghir, C. and E. Whitehouse (1996), The Evolution of Wages in the United Kingdom: Evidence from Micro Data, Journal of Labor Economics 14 (1), 1-25.

Möller, J. (2005), Die Entwicklung der Lohnspreizung in West- und Ostdeutschland. In: Bellmann, L., O. Hübler, W. Meyer and G. Stephan, Institutionen, Löhne und Beschäftigung, Beiträge zur Arbeitsmarkt und Berufsforschung 294, IAB Nürnberg, 47-63.

Pfeiffer, F. (2003), Lohnrigiditäten im gemischten Lohnbildungssystem, ZEW Wirtschaftsanalysen 65, Baden-Baden.

Pfeiffer, F. (2005), Existenzgründungen: Ein Weg zur Beschäftigungsförderung?, Zeitschrift für Arbeitsmarktforschung 38 (2-3), 325-340.

Prasad, E. S. (2004), The Unbearable Stability of the German Wage Structure: Evidence and Interpretation, IMF Staff Papers 51 (2), 354-285.

Riphahn, R. T. (2003), Bruttoeinkommensverteilung in Deutschland 1984-1999 und Ungleichheit unter ausländischen Erwerbstätigen. In: Schmähl, W., Wechselwirkungen zwischen Arbeitsmarkt und Sozialer Sicherung II, Schriften des Vereins für Socialpolitik 294, 135-174. 
Schuetz, G., H. W. Ursprung and L. Woessmann (2005), Education Policy and Equality of Opportunity, CESIFO Working Paper 1518.

Spitz-Oener, A. (2006), Technical Change, Job Tasks and Rising Educational Demands: Looking Outside the Wage Structure, Journal of Labor Economics, (in print).

Statistisches Bundesamt (2005), Statistisches Jahrbuch 2005 für die Bundesrepublik Deutschland, Wiesbaden (Statistisches Bundesamt).

Statistisches Bundesamt (1995), Statistisches Jahrbuch 1995 für die Bundesrepublik Deutschland, Wiesbaden (Statistisches Bundesamt).

Steiner, V. and T. Hölzle (2000), The Development of Wages in Germany in the 1990s - Descriptions and Explanations. In: Hauser, R. and I. Becker, The Personal Distribution of Income in an International Perspective, 7-30, Berlin (Springer).

Steiner, V. and K. Wagner (1998), Has Earnings Inequality in Germany Changed in the 1980's?, Zeitschrift für Wirtschafts- und Sozialwissenschaften 118, 29-59.

Taber C. R. (2001), The Rising College Premium in the Eighties: Return to College or Return to Unobserved Ability? The Review of Economic Studies 68 (3), 665691. 


\section{Appendix}

Table A1: Selected Studies on Wage Inequality in Germany

\begin{tabular}{|c|c|c|c|}
\hline Study & Time & Data & Results \\
\hline $\begin{array}{l}\text { Bellmann and Gart- } \\
\text { ner (2003) }\end{array}$ & $1975-2000$ & $\begin{array}{l}\text { IABS, } \\
\text { BLH }\end{array}$ & $\begin{array}{l}\text { Increasing wage dispersion in the } 1990 \text { s in } \\
\text { West Germany, especially within high wage } \\
\text { sectors. }\end{array}$ \\
\hline Fitzenberger (1999) & $1975-1990$ & IABS & $\begin{array}{l}\text { The wage dispersion within skill groups is sta- } \\
\text { ble over time for low skilled workers but in- } \\
\text { creases for medium and high skilled workers. } \\
\text { After controlling for age and cohort effects } \\
\text { there is increasing wage inequality within the } \\
\text { group of low skilled workers. }\end{array}$ \\
\hline $\begin{array}{l}\text { Fitzenberger, } \\
\text { Hujer, } \\
\text { MaCurdy and } \\
\text { Schnabel (2001) }\end{array}$ & $1976-1984$ & IABS & $\begin{array}{l}\text { Wage compression at the lower part of the } \\
\text { wage distribution which seems constant over } \\
\text { the surveyed time. The main findings are that } \\
\text { wages of workers with intermediate education } \\
\text { levels, among them especially those of young } \\
\text { workers, deteriorated slightly relative to high } \\
\text { and low education levels. }\end{array}$ \\
\hline $\begin{array}{l}\text { Franz and Steiner } \\
(2000)\end{array}$ & $1990-1997$ & GSOEP & $\begin{array}{l}\text { In East Germany wage distribution was com- } \\
\text { pressed under socialism. After unification there } \\
\text { is rising wage inequality in East Germany, } \\
\text { strongest in the first years. }\end{array}$ \\
\hline $\begin{array}{l}\text { Gernandt and } \\
\text { Pfeiffer (2006) }\end{array}$ & $1975-1995$ & IABS & $\begin{array}{l}\text { Rising wage inequality between job stayers and } \\
\text { entrants. }\end{array}$ \\
\hline Möller (2005) & $1975-2001$ & IABS & $\begin{array}{l}\text { Rising wage inequality, especially below the } \\
\text { median, starting from the mid 1990s. }\end{array}$ \\
\hline Pfeiffer (2003) & 1975-1995 & IABS & $\begin{array}{l}\text { Wage rigidity is present due to central wage } \\
\text { bargaining; for } 50 \text { percent of workers wages } \\
\text { would have been lower without rigidity; the } \\
\text { wage sweep-up is higher for German workers } \\
\text { in large firms, rises with tenure and is higher in } \\
\text { the middle part of the wage distribution. }\end{array}$ \\
\hline Prasad (2004) & 1984-1997 & GSOEP & $\begin{array}{l}\text { Relatively stable wage distribution in Ger- } \\
\text { many. Returns to education and experience } \\
\text { remained stable. Some evidence for a modest } \\
\text { increase in wage inequality at mid 1990s. }\end{array}$ \\
\hline $\begin{array}{l}\text { Steiner and Hölzle } \\
\text { (2000) }\end{array}$ & $1990-1997$ & GSOEP & $\begin{array}{l}\text { Relatively stable wage distribution in Ger- } \\
\text { many. Earnings and wage inequality in East } \\
\text { Germany increased after reunification. }\end{array}$ \\
\hline $\begin{array}{l}\text { Steiner and Wagner } \\
\text { (1998) }\end{array}$ & $1984-1990$ & $\begin{array}{l}\text { GSOEP, } \\
\text { IABS }\end{array}$ & $\begin{array}{l}\text { Modest increase in earnings inequality when } \\
\text { calculated on the basis of the IABS, while } \\
\text { earnings remained constant or slightly de- } \\
\text { creased on the basis of the GSOEP. }\end{array}$ \\
\hline
\end{tabular}


Table A2: Education Categories West Germany

\begin{tabular}{cccccc}
\hline \hline $\begin{array}{c}\text { No qualifica- } \\
\text { tion, no voca- } \\
\text { tional training }\end{array}$ & $\begin{array}{c}\text { School quali- } \\
\text { fication, no } \\
\text { vocational }\end{array}$ & $\begin{array}{c}\text { Medium } \\
\text { school qualifi- } \\
\text { cation, voca- } \\
\text { training (\%) }\end{array}$ & $\begin{array}{c}\text { Highest school } \\
\text { qualification, } \\
\text { tocal training } \\
\text { vocational } \\
\text { training (\%) }\end{array}$ & $\begin{array}{c}\text { Degree from } \\
\text { "Fachhochschule" } \\
(\%)\end{array}$ & $\begin{array}{c}\text { Degree from } \\
\text { university (\%) }\end{array}$ \\
& & $(\%)$ & & \\
\hline
\end{tabular}

\begin{tabular}{|c|c|c|c|c|c|c|}
\hline \multicolumn{7}{|c|}{ All Workers } \\
\hline 2004 & 1.09 & 10.14 & 52.01 & 15.12 & 8.12 & 13.53 \\
\hline 2003 & 1.48 & 10.30 & 51.77 & 15.05 & 8.16 & 13.24 \\
\hline 2002 & 1.39 & 10.87 & 51.42 & 14.96 & 8.15 & 13.21 \\
\hline 2001 & 1.44 & 11.29 & 52.85 & 14.18 & 7.81 & 12.42 \\
\hline 2000 & 1.58 & 11.94 & 52.62 & 14.05 & 7.47 & 12.35 \\
\hline 1999 & 2.93 & 14.15 & 49.38 & 14.69 & 6.76 & 12.10 \\
\hline 1998 & 2.59 & 13.76 & 49.77 & 15.28 & 7.09 & 11.50 \\
\hline 1997 & 3.07 & 15.30 & 50.63 & 14.42 & 5.83 & 10.76 \\
\hline 1996 & 2.22 & 14.87 & 52.49 & 13.86 & 5.74 & 10.83 \\
\hline 1995 & 2.23 & 16.60 & 50.26 & 13.79 & 5.89 & 11.22 \\
\hline 1994 & 2.86 & 16.67 & 51.80 & 13.64 & 4.64 & 10.39 \\
\hline 1993 & 2.90 & 18.85 & 51.10 & 13.72 & 4.11 & 9.32 \\
\hline 1992 & 3.11 & 18.82 & 51.90 & 12.88 & 4.35 & 8.94 \\
\hline 1991 & 3.30 & 19.85 & 51.70 & 12.74 & 4.07 & 8.34 \\
\hline 1990 & 2.61 & 18.11 & 53.59 & 12.43 & 4.43 & 8.83 \\
\hline 1989 & 2.59 & 16.34 & 54.08 & 14.05 & 3.85 & 9.08 \\
\hline 1988 & 2.31 & 16.17 & 53.38 & 14.06 & 4.46 & 9.62 \\
\hline 1987 & 2.31 & 16.83 & 54.49 & 13.57 & 4.10 & 8.69 \\
\hline 1986 & 2.22 & 15.81 & 53.54 & 14.05 & 4.56 & 9.82 \\
\hline 1985 & 2.09 & 15.95 & 53.76 & 13.80 & 4.56 & 9.84 \\
\hline 1984 & 2.47 & 16.53 & 55.53 & 13.25 & 4.17 & 8.05 \\
\hline \multicolumn{7}{|c|}{ Prime Age Dependent Male Workers } \\
\hline 2004 & 1.37 & 9.12 & 47.65 & 18.04 & 10.21 & 13.60 \\
\hline 2003 & 1.50 & 9.73 & 47.66 & 17.51 & 10.38 & 13.22 \\
\hline 2002 & 1.53 & 9.61 & 48.15 & 17.54 & 9.78 & 13.40 \\
\hline 2001 & 1.49 & 9.62 & 49.93 & 17.07 & 10.01 & 11.88 \\
\hline 2000 & 1.66 & 10.42 & 49.73 & 17.05 & 9.06 & 12.08 \\
\hline 1999 & 2.78 & 12.58 & 48.34 & 15.54 & 7.50 & 13.27 \\
\hline 1998 & 2.63 & 11.89 & 46.66 & 17.84 & 8.23 & 12.74 \\
\hline 1997 & 2.90 & 12.53 & 48.18 & 16.21 & 7.44 & 12.74 \\
\hline 1996 & 2.02 & 12.40 & 49.23 & 17.40 & 6.32 & 12.63 \\
\hline 1995 & 1.64 & 12.22 & 47.36 & 17.60 & 7.11 & 14.07 \\
\hline 1994 & 2.61 & 12.12 & 48.70 & 17.64 & 6.07 & 12.86 \\
\hline 1993 & 2.70 & 12.99 & 48.69 & 17.58 & 5.82 & 12.23 \\
\hline 1992 & 2.86 & 12.78 & 49.11 & 17.79 & 5.86 & 11.60 \\
\hline 1991 & 2.92 & 13.79 & 49.82 & 16.71 & 5.77 & 10.98 \\
\hline 1990 & 2.78 & 11.47 & 52.12 & 16.18 & 6.11 & 11.35 \\
\hline 1989 & 2.56 & 10.59 & 51.92 & 18.22 & 5.28 & 11.43 \\
\hline 1988 & 2.23 & 10.80 & 51.48 & 17.78 & 5.62 & 12.09 \\
\hline 1987 & 2.25 & 11.17 & 53.62 & 16.67 & 5.06 & 11.25 \\
\hline 1986 & 2.14 & 10.52 & 51.61 & 17.52 & 5.28 & 12.92 \\
\hline 1985 & 2.08 & 10.42 & 51.51 & 17.51 & 5.55 & 12.93 \\
\hline 1984 & 2.61 & 11.67 & 54.09 & 16.10 & 5.07 & 10.46 \\
\hline
\end{tabular}

Source: Samples from GSOEP 1984-2004, see text; weighted data; own calculations. 
Table A3: Summary of Statistics, West Germany

\begin{tabular}{|c|c|c|c|c|c|c|}
\hline & $\begin{array}{c}\text { Years of edu- } \\
\text { cation }\end{array}$ & Tenure & $\begin{array}{c}\text { Potential ex- } \\
\text { perience }\end{array}$ & Females (\%) & $\begin{array}{c}\begin{array}{c}\text { Foreigners } \\
(\%)^{19}\end{array} \\
\end{array}$ & $\begin{array}{c}\text { Self-employed } \\
(\%)\end{array}$ \\
\hline \multicolumn{7}{|c|}{ All Workers } \\
\hline 2004 & 12.33 & 11.26 & 23.75 & 46.62 & 4.98 & 7.51 \\
\hline 2003 & 12.36 & 11.12 & 23.44 & 46.54 & 8.13 & 6.63 \\
\hline 2002 & 12.34 & 10.73 & 23.27 & 45.22 & 8.42 & 6.35 \\
\hline 2001 & 12.26 & 10.62 & 23.00 & 44.73 & 8.35 & 6.04 \\
\hline 2000 & 12.23 & 10.63 & 22.80 & 43.93 & 8.29 & 5.55 \\
\hline 1999 & 12.03 & 10.71 & 23.01 & 43.37 & 7,72 & 6.71 \\
\hline 1998 & 11.97 & 11.05 & 22.88 & 42.61 & 7.69 & 6.21 \\
\hline 1997 & 11.82 & 10.72 & 22.63 & 42.72 & 8.24 & 6.52 \\
\hline 1996 & 11.83 & 10.68 & 22.45 & 42.85 & 7.17 & 5.96 \\
\hline 1995 & 11.82 & 11.31 & 22.35 & 41.57 & 7.83 & 5.43 \\
\hline 1994 & 11.70 & 11.01 & 22.19 & 42.09 & 8.64 & 5.03 \\
\hline 1993 & 11.57 & 10.46 & 22.42 & 41.93 & 8.73 & 4.06 \\
\hline 1992 & 11.52 & 10.12 & 21.90 & 41.06 & 8.83 & 4.56 \\
\hline 1991 & 11.45 & 10.83 & 21.96 & 40.75 & 9.27 & 4.45 \\
\hline 1990 & 11.53 & 10.77 & 21.63 & 39.63 & 7.75 & 4.50 \\
\hline 1989 & 11.56 & 10.66 & 21.17 & 38.73 & 7.33 & 4.62 \\
\hline 1988 & 11.61 & 11.02 & 21.62 & 38.54 & 6.76 & 4.68 \\
\hline 1987 & 11.49 & 10.89 & 21.67 & 38.46 & 7.03 & 6.06 \\
\hline 1986 & 11.58 & 10.79 & 21.40 & 37.87 & 7.17 & 5.24 \\
\hline 1985 & 11.56 & 10.98 & 21.79 & 37.67 & 6.74 & 6.72 \\
\hline 1984 & 11.40 & 10.94 & 21.81 & 36.65 & 7.00 & 6.85 \\
\hline \multicolumn{7}{|c|}{ Prime Age Dependent Male Workers } \\
\hline 2004 & 12.45 & 11.58 & 22.07 & . & 5.60 & . \\
\hline 2003 & 12.44 & 11.58 & 21.89 & . & 9.16 & . \\
\hline 2002 & 12.41 & 11.05 & 21.64 & . & 9.48 & . \\
\hline 2001 & 12.29 & 10.87 & 21.39 & . & 9.45 & . \\
\hline 2000 & 12.26 & 10.96 & 21.19 & . & 9.26 & . \\
\hline 1999 & 12.10 & 11.12 & 21.54 & . & 8.96 & . \\
\hline 1998 & 12.02 & 11.03 & 21.02 & . & 8.50 & . \\
\hline 1997 & 12.02 & 11.13 & 21.01 & . & 8.20 & . \\
\hline 1996 & 11.93 & 10.99 & 20.79 & . & 6.99 & . \\
\hline 1995 & 12.06 & 12.10 & 21.39 & . & 7.69 & . \\
\hline 1994 & 11.93 & 12.30 & 21.39 & . & 8.86 & . \\
\hline 1993 & 11.91 & 11.68 & 21.58 & . & 8.64 & . \\
\hline 1992 & 11.81 & 11.55 & 21.67 & . & 9.72 & . \\
\hline 1991 & 11.74 & 11.89 & 21.60 & . & 10.71 & . \\
\hline 1990 & 11.84 & 11.98 & 21.78 & . & 8.75 & . \\
\hline 1989 & 11.83 & 11.80 & 21.55 & . & 8.76 & . \\
\hline 1988 & 11.84 & 11.92 & 21.65 & . & 8.47 & . \\
\hline 1987 & 11.67 & 12.08 & 22.04 & . & 8.50 & . \\
\hline 1986 & 11.84 & 11.74 & 21.68 & . & 8.82 & . \\
\hline 1985 & 11.84 & 11.99 & 21.91 & . & 8.09 & . \\
\hline 1984 & 11.60 & 12.10 & 22.40 & . & 7.82 & . \\
\hline
\end{tabular}

Source: Samples from GSOEP 1984-2004, see text; weighted data; own calculations.

\footnotetext{
${ }^{19}$ After using the weights there is a strong decrease of the foreign share. For example in 1984 the non-weighted share of foreigners was about 27\% in West Germany. In 2003 the non-weighted share of employees was 10.98\% and decreases to $9.95 \%$ in 2004 . The huge decrease of the weighted foreigners share to $4.98 \%$ in 2004 seems surprisingly.
} 
Table A4: Means of Real Wages and Hours, East Germany

\begin{tabular}{ccccccccc}
\hline \hline & All Workers & & \multicolumn{3}{c}{ Prime Age Dependent Male Workers } \\
\hline & $\begin{array}{c}\text { Obser- } \\
\text { vations }\end{array}$ & $\begin{array}{c}\text { Real gross } \\
\text { monthly } \\
\text { salary }\end{array}$ & $\begin{array}{c}\text { Weekly } \\
\text { hours } \\
\text { worked }\end{array}$ & $\begin{array}{c}\text { Real } \\
\text { gross } \\
\text { hourly } \\
\text { wage }\end{array}$ & $\begin{array}{c}\text { Obser- } \\
\text { vations }\end{array}$ & $\begin{array}{c}\text { Real gross } \\
\text { monthly } \\
\text { salary }\end{array}$ & $\begin{array}{c}\text { Weekly } \\
\text { hours } \\
\text { worked }\end{array}$ & $\begin{array}{c}\text { Real } \\
\text { gross } \\
\text { hourly } \\
\text { wage }\end{array}$ \\
\hline $\mathbf{2 0 0 4}$ & 1,923 & $1,935.84$ & 41.45 & 10.75 & 739 & $2,212.54$ & 44.58 & 11.53 \\
$\mathbf{2 0 0 3}$ & 1,967 & $1,963.00$ & 41.92 & 10.81 & 762 & $2,204.08$ & 44.83 & 11.43 \\
$\mathbf{2 0 0 2}$ & 2,050 & $1,894.60$ & 41.89 & 10.44 & 802 & $2,067.13$ & 44.45 & 10.75 \\
$\mathbf{2 0 0 1}$ & 2,220 & $1,840.29$ & 42.07 & 10.17 & 882 & $2,010.83$ & 45.24 & 10.38 \\
$\mathbf{2 0 0 0}$ & 2,336 & $1,807.30$ & 42.51 & 9.85 & 931 & $1,942.60$ & 45.19 & 9.99 \\
$\mathbf{1 9 9 9}$ & 1,668 & $1,812.94$ & 42.76 & 9.81 & 691 & $1,881.43$ & 44.98 & 9.72 \\
$\mathbf{1 9 9 8}$ & 1,632 & $1,802.80$ & 42.70 & 9.83 & 694 & $1,918.14$ & 45.19 & 9.94 \\
$\mathbf{1 9 9 7}$ & 1,610 & $1,823.10$ & 43.74 & 9.69 & 690 & $1,917.13$ & 45.98 & 9.71 \\
$\mathbf{1 9 9 6}$ & 1,673 & $1,788.53$ & 43.33 & 9.60 & 728 & $1,892.12$ & 46.26 & 9.57 \\
$\mathbf{1 9 9 5}$ & 1,751 & $1,721.38$ & 43.51 & 9.20 & 771 & $1,856.05$ & 46.34 & 9.31 \\
$\mathbf{1 9 9 4}$ & 1,710 & $1,672.61$ & 43.46 & 8.92 & 797 & $1,776.50$ & 45.66 & 9.04 \\
$\mathbf{1 9 9 3}$ & 1,772 & $1,537.08$ & 43.65 & 8.19 & 820 & $1,639.47$ & 45.87 & 8.34 \\
$\mathbf{1 9 9 2}$ & 1,967 & $1,298.04$ & 43.24 & 6.94 & 906 & $1,401.96$ & 45.14 & 7.22 \\
$\mathbf{1 9 9 1}$ & 2,120 & $1,035.05$ & 41.04 & 5.90 & 916 & $1,170.95$ & 43.13 & 6.37 \\
\hline \hline
\end{tabular}

Source: Samples from GSOEP 1984-2004, see text; weighted data; own calculations.

Table A5: Wage Inequality in East Germany: $90^{\text {th }}$ to $10^{\text {th }}$ Wage Percentiles

\begin{tabular}{|c|c|c|c|c|c|c|}
\hline & \multicolumn{3}{|c|}{ All Workers } & \multicolumn{3}{|c|}{ Prime Age Dependent Male Workers } \\
\hline & 1984 & 1994 & 2004 & 1984 & 1994 & 2004 \\
\hline All & 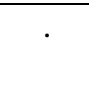 & $\begin{array}{c}2.40 \\
(2.32-2.48)\end{array}$ & $\begin{array}{c}3.02 \\
(2.88-3.15)\end{array}$ & . & $\begin{array}{c}2.26 \\
(2.15-2.38)\end{array}$ & $\begin{array}{c}2.87 \\
(2.70-3.04)\end{array}$ \\
\hline Females & . & $\begin{array}{c}2.42 \\
(2.30-2.53)\end{array}$ & $\begin{array}{c}3.00 \\
(2.83-3.17)\end{array}$ & . & . & . \\
\hline Foreigners & . & 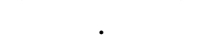 & . & . & . & . \\
\hline Self-employed & . & $\begin{array}{l}4.79 \\
\text { (n.a.) }\end{array}$ & $\begin{array}{c}3.61 \\
(3.00-4.22)\end{array}$ & . & . & . \\
\hline High educated & . & $\begin{array}{c}2.33 \\
(2.17-2.50)\end{array}$ & $\begin{array}{c}2.88 \\
(2.64-3.12)\end{array}$ & . & $\begin{array}{c}2.17 \\
(1.98-2.36)\end{array}$ & $\begin{array}{c}2.59 \\
(2.23-2.94)\end{array}$ \\
\hline Low educated & . & $\begin{array}{c}2.13 \\
(2.05-2.20)\end{array}$ & $\begin{array}{c}2.60 \\
(2.50-2.70)\end{array}$ & . & $\begin{array}{c}2.02 \\
(1.91-2.13)\end{array}$ & $\begin{array}{c}2.42 \\
(2.22-2.61)\end{array}$ \\
\hline High tenure & . & $\begin{array}{c}2.24 \\
(2.10-2.37)\end{array}$ & $\begin{array}{c}2.91 \\
(2.77-3.05)\end{array}$ & . & $\begin{array}{c}2.21 \\
(2.02-2.40)\end{array}$ & $\begin{array}{c}2.77 \\
(2.51-3.03)\end{array}$ \\
\hline Low tenure & . & $\begin{array}{c}2.40 \\
(2.29-2.52)\end{array}$ & $\begin{array}{c}2.73 \\
(2.56-2.90)\end{array}$ & . & $\begin{array}{c}2.27 \\
(2.12-2.43)\end{array}$ & $\begin{array}{c}2.71 \\
(2.46-2.96)\end{array}$ \\
\hline High experience & . & $\begin{array}{c}2.42 \\
(2.30-2.55)\end{array}$ & $\begin{array}{c}3.06 \\
(2.88-3.23)\end{array}$ & . & $\begin{array}{c}2.27 \\
(2.12-2.42)\end{array}$ & $\begin{array}{c}3.04 \\
(2.75-3.33)\end{array}$ \\
\hline Low experience & . & $\begin{array}{c}2.32 \\
(2.19-2.46)\end{array}$ & $\begin{array}{c}2.93 \\
(2.74-3.13)\end{array}$ & . & $\begin{array}{c}2.23 \\
(2.06-2.40)\end{array}$ & $\begin{array}{c}2.67 \\
(2.43-2.90)\end{array}$ \\
\hline
\end{tabular}

Source: Samples from GSOEP 1984-2004, see text; in brackets: 95\% confidence interval, calculated by bootstrapping (1,000 replications), own calculations. 
Table A6: Education Categories, East Germany

\begin{tabular}{|c|c|c|c|c|c|c|}
\hline & $\begin{array}{l}\text { No qualifica- } \\
\text { tion, no voca- } \\
\text { tional training } \\
(\%)\end{array}$ & $\begin{array}{l}\text { School quali- } \\
\text { fication, no } \\
\text { vocational } \\
\text { training (\%) }\end{array}$ & $\begin{array}{c}\text { Medium } \\
\text { school qualifi- } \\
\text { cation, voca- } \\
\text { tional training } \\
(\%)\end{array}$ & $\begin{array}{l}\text { Highest school } \\
\text { qualification, } \\
\text { vocational } \\
\text { training (\%) }\end{array}$ & $\begin{array}{c}\text { Degree from } \\
\text { "Fachhochschule" } \\
(\%)\end{array}$ & $\begin{array}{c}\text { Degree from } \\
\text { university (\%) }\end{array}$ \\
\hline \multicolumn{7}{|c|}{ All Workers } \\
\hline 2004 & 0.07 & 4.56 & 51.74 & 13.59 & 16.29 & 14.75 \\
\hline 2003 & 0.18 & 4.24 & 51.69 & 13.02 & 15.60 & 15.27 \\
\hline 2002 & . & 3.51 & 53.63 & 11.77 & 15.73 & 15.36 \\
\hline 2001 & 0.30 & 4.29 & 52.91 & 10.67 & 17.55 & 14.29 \\
\hline 2000 & 0.09 & 4.01 & 54.54 & 11.31 & 16.48 & 13.57 \\
\hline 1999 & 0.22 & 3.18 & 53.51 & 11.90 & 18.37 & 12.81 \\
\hline 1998 & 0.07 & 2.93 & 52.88 & 11.31 & 19.28 & 13.53 \\
\hline 1997 & 0.19 & 2.33 & 51.39 & 11.34 & 20.15 & 14.59 \\
\hline 1996 & 0.06 & 2.20 & 54.66 & 10.16 & 19.97 & 12.96 \\
\hline 1995 & 0.06 & 2.40 & 54.09 & 9.83 & 20.20 & 13.43 \\
\hline 1994 & 0.06 & 2.32 & 56.39 & 8.84 & 18.84 & 13.56 \\
\hline 1993 & 0.08 & 2.70 & 56.58 & 8.40 & 19.47 & 12.77 \\
\hline 1992 & 0.04 & 2.91 & 57.32 & 8.60 & 18.43 & 12.70 \\
\hline 1991 & 0.05 & 3.08 & 57.71 & 8.69 & 18.93 & 11.55 \\
\hline \multicolumn{7}{|c|}{ Prime Age Dependent Male Workers } \\
\hline 2004 & 0.18 & 4.23 & 57.71 & 13.79 & 9.39 & 14.71 \\
\hline 2003 & . & 4.33 & 55.51 & 15.00 & 9.92 & 15.24 \\
\hline 2002 & . & 3.65 & 57.30 & 13.31 & 9.75 & 15.99 \\
\hline 2001 & 0.48 & 5.16 & 59.54 & 11.36 & 9.75 & 13.72 \\
\hline 2000 & 0.13 & 4.78 & 60.76 & 11.81 & 9.20 & 13.32 \\
\hline 1999 & 0.14 & 3.18 & 60.92 & 14.77 & 7.90 & 13.09 \\
\hline 1998 & 0.07 & 2.86 & 59.85 & 13.03 & 9.43 & 14.76 \\
\hline 1997 & 0.14 & 1.68 & 57.68 & 14.28 & 9.49 & 16.73 \\
\hline 1996 & 0.13 & 1.11 & 61.81 & 12.89 & 10.26 & 13.78 \\
\hline 1995 & 0.13 & 1.52 & 59.63 & 13.54 & 10.79 & 14.39 \\
\hline 1994 & 0.13 & 1.50 & 61.41 & 12.56 & 10.43 & 13.97 \\
\hline 1993 & 0.17 & 1.34 & 60.86 & 11.21 & 11.86 & 14.57 \\
\hline 1992 & 0.10 & 1.72 & 60.34 & 12.13 & 12.30 & 13.42 \\
\hline 1991 & 0.11 & 1.73 & 58.94 & 12.82 & 13.25 & 13.16 \\
\hline
\end{tabular}

Source: GSOEP 1984-2004 Samples 1-3, 5-6; weighted data: individual cross sectional weight. 
Table A7: Summary Statistics, East Germany

\begin{tabular}{|c|c|c|c|c|c|c|}
\hline & $\begin{array}{c}\text { Years of edu- } \\
\text { cation }\end{array}$ & Tenure & $\begin{array}{c}\text { Potential ex- } \\
\text { perience }\end{array}$ & Females (\%) & $\begin{array}{c}\text { Foreigners } \\
(\%) \\
\end{array}$ & $\begin{array}{c}\text { Self-employed } \\
(\%)\end{array}$ \\
\hline \multicolumn{7}{|c|}{ All Workers } \\
\hline 2004 & 12.77 & 9.63 & 24.29 & 47.63 & 0.11 & 8.46 \\
\hline 2003 & 12.85 & 9.28 & 23.72 & 47.54 & 0.44 & 8.25 \\
\hline 2002 & 12.83 & 8.84 & 23.28 & 47.93 & 0.65 & 7.35 \\
\hline 2001 & 12.74 & 8.54 & 23.33 & 46.65 & 0.92 & 7.57 \\
\hline 2000 & 12.72 & 7.96 & 22.78 & 45.81 & 0.54 & 7.34 \\
\hline 1999 & 12.65 & 7.94 & 22.45 & 45.93 & . & 6.28 \\
\hline 1998 & 12.70 & 7.75 & 22.04 & 45.16 & 0.60 & 7.16 \\
\hline 1997 & 12.78 & 7.72 & 22.09 & 45.17 & 0.71 & 6.48 \\
\hline 1996 & 12.59 & 7.51 & 22.14 & 46.30 & 0.24 & 4.77 \\
\hline 1995 & 12.64 & 7.72 & 21.82 & 44.80 & 1.40 & 5.21 \\
\hline 1994 & 12.60 & 8.24 & 21.23 & 45.01 & 0.83 & 3.89 \\
\hline 1993 & 12.57 & 7.19 & 20.67 & 45.69 & 0.30 & 3.80 \\
\hline 1992 & 12.50 & 8.60 & 20.74 & 44.77 & 1.03 & 2.82 \\
\hline 1991 & 12.39 & . & 21.21 & 45.38 & 0.57 & 2.55 \\
\hline \multicolumn{7}{|c|}{ Prime Age Dependent Male Workers } \\
\hline 2004 & 12.70 & 9.01 & 22.64 &. & 0.18 & . \\
\hline 2003 & 12.79 & 9.22 & 22.60 & . & 0.93 & . \\
\hline 2002 & 12.77 & 8.42 & 22.07 & . & 1.47 & . \\
\hline 2001 & 12.52 & 8.28 & 21.76 & . & . & . \\
\hline 2000 & 12.58 & 7.64 & 21.74 & . & 0.11 & . \\
\hline 1999 & 12.53 & 7.59 & 21.50 & . & . & . \\
\hline 1998 & 12.59 & 7.53 & 21.22 & . & 1.20 & . \\
\hline 1997 & 12.73 & 7.35 & 21.27 & . & 1.42 & . \\
\hline 1996 & 12.51 & 7.33 & 21.22 & . & 0.09 & . \\
\hline 1995 & 12.57 & 7.61 & 21.08 & . & 2.72 & . \\
\hline 1994 & 12.52 & 8.40 & 20.79 & . & 1.30 & . \\
\hline 1993 & 12.58 & 7.55 & 20.91 & . & 0.34 & . \\
\hline 1992 & 12.52 & 9.06 & 21.14 & . & 1.65 & . \\
\hline 1991 & 12.47 & . & 21.36 & . & 0.66 & . \\
\hline
\end{tabular}

Source: GSOEP 1984-2004 Samples 1-3, 5-6; weighted data: individual cross sectional weight. 
Table A8: Decomposition Results in Education Groups, East Germany 1994-2004

\begin{tabular}{|c|c|c|c|c|}
\hline Differential & Total & Quantities & Prices & Unobserved \\
\hline \multicolumn{5}{|c|}{ Without school qualification and without vocational training ${ }^{20}$} \\
\hline 90-10 & . & . & . & . \\
\hline 90-50 & . & . & . & . \\
\hline $50-10$ & . & . & . & . \\
\hline \multicolumn{5}{|c|}{ With school qualification but without vocational training } \\
\hline 90-10 & 0.284 & 0.070 & 0.061 & 0.153 \\
\hline $90-50$ & 0.183 & -0.010 & 0.095 & 0.098 \\
\hline $50-10$ & 0.102 & 0.080 & -0.034 & 0.055 \\
\hline \multicolumn{5}{|c|}{ With medium school qualification (without Abitur) and with vocational training } \\
\hline 90-10 & 0.208 & 0.013 & 0.065 & 0.131 \\
\hline 90-50 & 0.153 & 0.012 & 0.061 & 0.080 \\
\hline $50-10$ & 0.055 & 0.000 & 0.004 & 0.051 \\
\hline \multicolumn{5}{|c|}{$\begin{array}{c}\text { With highest school qualification (Abitur) and with vocational training, } \\
\text { also "Beamte, Handelsschule, Techniker" }\end{array}$} \\
\hline $90-10$ & 0.080 & 0.073 & -0.068 & 0.076 \\
\hline $90-50$ & 0.051 & 0.141 & -0.100 & 0.010 \\
\hline $50-10$ & 0.029 & -0.069 & 0.032 & 0.066 \\
\hline \multicolumn{5}{|c|}{ Degree from a "Fachhochschule" } \\
\hline 90-10 & 0.248 & 0.008 & 0.097 & 0.144 \\
\hline $90-50$ & 0.117 & -0.014 & 0.068 & 0.063 \\
\hline $50-10$ & 0.132 & 0.022 & 0.029 & 0.081 \\
\hline \multicolumn{5}{|c|}{ Degree from a university } \\
\hline 90-10 & 0.119 & 0.015 & 0.007 & 0.097 \\
\hline $90-50$ & -0.028 & 0.049 & -0.104 & 0.027 \\
\hline $50-10$ & 0.146 & -0.034 & 0.111 & 0.070 \\
\hline
\end{tabular}

Source: GSOEP 1984-2004 Samples 1-3, 5-6; own calculations. ${ }^{20}$ There are not enough observations in East Germany for persons without school qualifications and without voca-
tional training. 
Table A9: Decomposition Results in Tenure and Potential Experience Groups, East Germany 1994-2004

\begin{tabular}{|c|c|c|c|c|}
\hline Differential & Total & Quantities & Prices & Unobserved \\
\hline \multicolumn{5}{|c|}{ Low tenure } \\
\hline 90-10 & 0.128 & -0.006 & 0.065 & 0.176 \\
\hline $90-50$ & 0.136 & 0.043 & 0.042 & 0.051 \\
\hline $50-10$ & -0.009 & -0.049 & 0.023 & 0.017 \\
\hline \multicolumn{5}{|c|}{ High tenure } \\
\hline 90-10 & 0.261 & 0.027 & 0.059 & 0.176 \\
\hline $90-50$ & 0.136 & 0.003 & 0.049 & 0.084 \\
\hline $50-10$ & 0.125 & 0.024 & 0.009 & 0.092 \\
\hline \multicolumn{5}{|c|}{ Low potential experience } \\
\hline 90-10 & 0.234 & 0.044 & 0.089 & 0.101 \\
\hline $90-50$ & 0.164 & 0.049 & 0.062 & 0.053 \\
\hline $50-10$ & 0.069 & -0.005 & 0.027 & 0.048 \\
\hline \multicolumn{5}{|c|}{ High potential experience } \\
\hline 90-10 & 0.250 & 0.005 & 0.108 & 0.137 \\
\hline $90-50$ & 0.158 & 0.013 & 0.081 & 0.064 \\
\hline $50-10$ & 0.093 & -0.008 & 0.027 & 0.074 \\
\hline
\end{tabular}

Source: GSOEP 1984-2004 Samples 1-3, 5-6; own calculations. 